\title{
Seismotectonics of the Padanian Region and Surrounding Belts: Which Driving Mechanism?
}

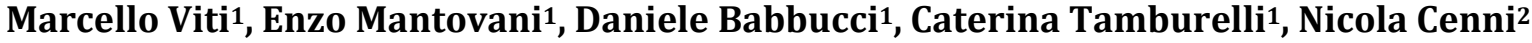 \\ ${ }^{1}$ Dipartimento di Scienze Fisiche, Della Terra e dell'Ambiente, Università degli Studi di Siena, Siena, Italy \\ ${ }^{2}$ Dipartimento di Fisica ed Astronomia, Università degli Studi di Bologna, Bologna, Italy \\ Email: marcello.viti@unisi.it
}

How to cite this paper: Viti, M., Mantovani, E., Babbucci, D., Tamburelli, C. and Cenni, N. (2016) Seismotectonics of the Padanian Region and Surrounding Belts: Which Driving Mechanism? International Journal of Geosciences, 7, 1412-1451. http://dx.doi.org/10.4236/ijg.2016.712100

Received: October 20, 2016

Accepted: December 26, 2016

Published: December 29, 2016

Copyright $\odot 2016$ by authors and Scientific Research Publishing Inc. This work is licensed under the Creative Commons Attribution International License (CC BY 4.0).

http://creativecommons.org/licenses/by/4.0/

\begin{abstract}
It is argued that the complex tectonic pattern observed in the study area can plausibly be explained as an effect of the kinematics of the Iberia and Adria blocks, induced by the NNE ward motion of Africa and the roughly westward motion of the Anatolian-Aegean system with respect to Eurasia. These boundary conditions cause the constrictional regime which is responsible for the observed shortening processes in the Padanian region and Western Alps. The proposed dynamic context can plausibly account for the peculiar distribution of major seismic sources, located in the northern Apennines, the Giudicarie fault system, the offshore of the western Ligurian coast and the Swiss Alps. The observed tectonic pattern in Western Europe and the study area can hardly be reconciled with the implications of the roughly NWward convergence between Africa and Eurasia proposed by global kinematic models, whereas it is compatible with the alternative Africa-Eurasia kinematics and plate mosaic proposed by [1].
\end{abstract}

\section{Keywords}

Seismotectonics, Geodynamics, GPS, Mediterranean, Padanian

\section{Introduction}

It is largely recognized that seismotectonic activity in the eastern Southern Alps, lying east of the Schio-Vicenza fault system, is caused by the indentation of the main Adriatic plate [2] [3] [4] [5], whereas a largely accepted geodynamic interpretation of the tectonic setting in the northern Italian area lying West of the Schio-Vicenza line, comprising the Padanian area and the surrounding Alpine and Apennine belts (Figure 1) is not yet available.

This last zone (Figure 1) mainly corresponds to the northwestern protuberance of 


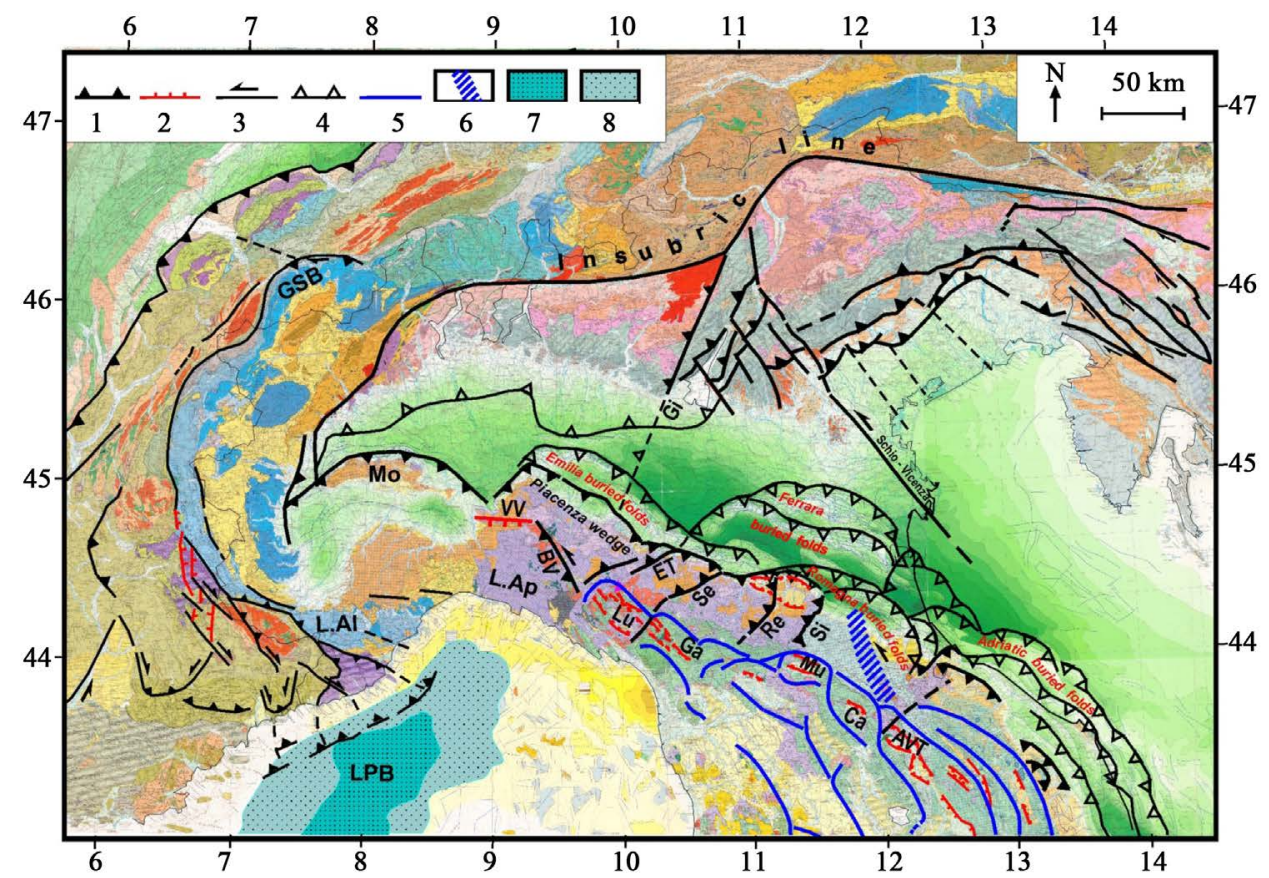

Figure 1. Tectonic sketch of the Padanian zone and surrounding belts, reported on the Structural Map of Italy [15]. 1, 2, 3) Main compressional, extensional and transcurrent features. 4) Fronts of buried folds 5) Main ridge crests 6) Romagna-Forlì seismic alignment 7, 8) Very thinned and thinned areas in the Ligurian basin.. AVT = Alta Val Tiberina trough, BV = Bedonia-Varzi fault system, $\mathrm{Ca}=$ Casentino trough, $\mathrm{ET}=$ Enza-Taro fault system, $\mathrm{Ga}=$ Garfagnana trough, $\mathrm{Gi}=$ Giudicarie fault system, GSB = Grand Saint Bernard arc, L.Al = Ligurian Alpine units, L.Ap = Ligurian Apennine units, LPB = Liguro-Provencal basin, Lu = Lunigiana trough, $\mathrm{Mu}=$ Mugello trough, Mo = Monferrato arc, $\mathrm{Re}=$ Reno thrust front, $\mathrm{Se}=$ Secchia thrust front, $\mathrm{Si}=$ Sillaro trust front, VV = Villarvernia-Varzi fault system.

the Adriatic plate buried below the Po valley and overthrusted by the Alpine belt, from North and West, and by the Northern Apennines, from South. The two involved foredeeps have formed the large Padanian basin [6]-[12]. The fact that such region has been hit by several intermediate and strong earthquakes (Figure 2), associated with various strain styles and focal depths, suggests that significant tectonic activity is still going on and is characterized by a complex pattern [13] [14]. An important constraint to the present tectonic setting is given by the peculiar distribution of major seismic sources $(\mathrm{M}>5.5)$, located in the Central Alps (Verona zone), Western Alps, Ligurian basin, Ferrara and Emilia buried folds, Romagna Apennines and pede Padanian Apennine belt (Figure 2).

Various geodynamic interpretations have been proposed for the evolution of the Apennine belt, mainly involving subcrustal processes. The most cited model invokes the retreat of the Adriatic lithosphere subducted beneath the Apennine belt, possibly induced by slab pull or mantle flow, as the main driving mechanism of surface deformation [17] [18] [19] [20] [21].

However, such interpretation can hardly provide plausible explanations for some major evidence, as argued in the following: 


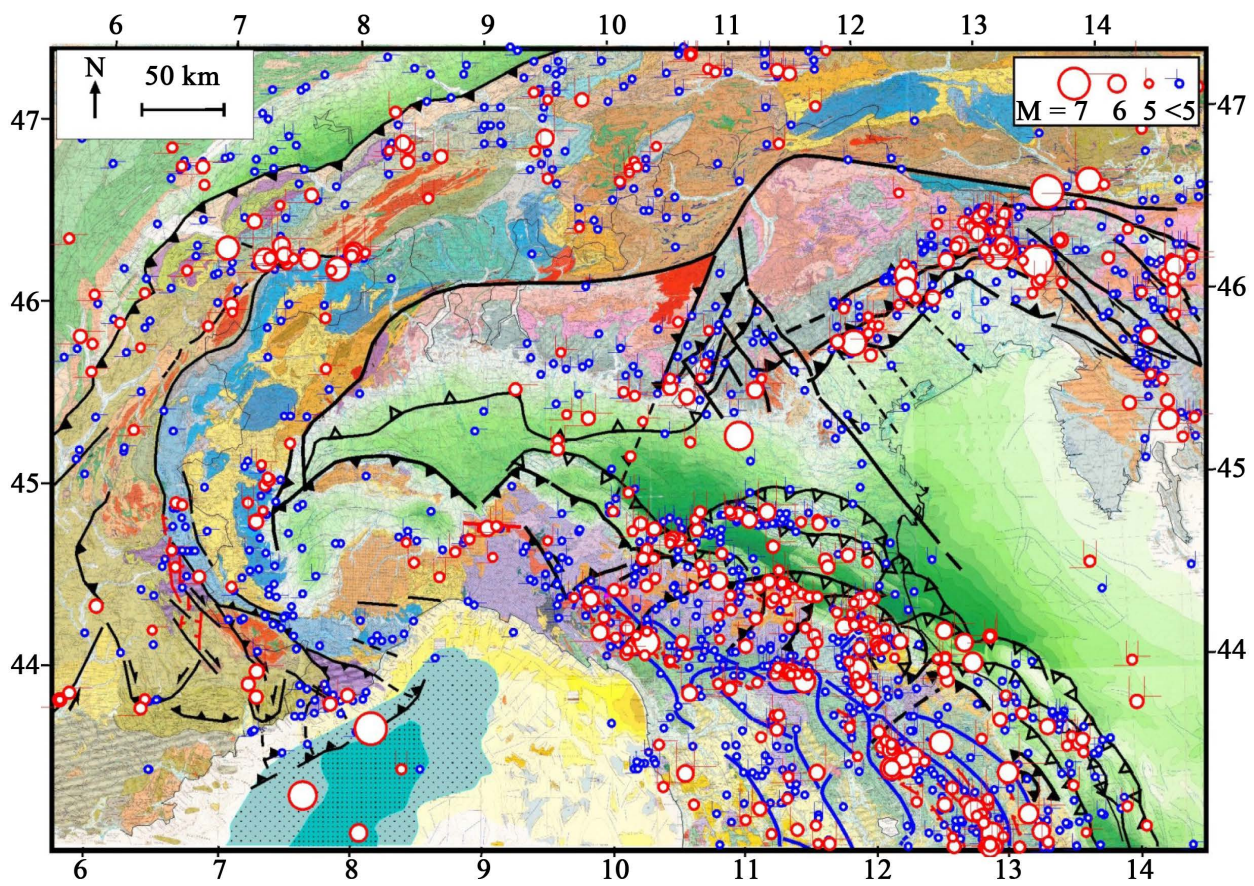

Figure 2. Major earthquakes (red circles, $M>4$ ) that have occurred in the study area since 1000 A.D. [16] reported on the Structural Map of Italy [15].

1) Slab retreat can only occur when a well-developed lithospheric body is present (200 km long at least [22] [23]. However, this feature is not compatible with the results of deep seismic surveys and recent tomographic analyses, both suggesting the absence of a long Adriatic slab beneath the Northern Apennines [24] [25].

2) Subcrustal seismic activity beneath the Northern Apennines is very weak, with magnitudes lower than 5 [26]. Furthermore, focal depths are mostly lower than $70 \mathrm{~km}$ [27] [28] [29]. This evidence can hardly be reconciled with the presence of a tectonically active, well-developed slab. In the zones of the world where the presence of a long lithospheric body is suggested by the occurrence of deep seismic activity, as observed for instance in the southern Tyrrhenian zone, major earthquakes are recognized up to depths of about $500 \mathrm{~km} \mathrm{[30].}$

3) Slab-retreat is inhibited when continental lithosphere enters the subduction zone [31]. Since the Adriatic lithosphere which underthrusts the Northern Apennines is continental [24], the occurrence of a slab-retreat process in that context is not plausible.

4) The sector of the Northern Apennines buried under the Po Valley (Figure 1) is characterized by a series of structural arcs, known from West to East as the Monferrato, Emilia, Romagna, Ferrara and Adriatic Folds [7] [32] [33] [34]. Explaining the development of such peculiar tectonic pattern is not trivial, as discussed by [35], who suggests that the above arcs mostly developed since late Miocene within a dextral transpressional deformation regime. Other authors [36] explain the recent evolution of the Northern Apennines in the framework of a belt-parallel transpressional regime. More in general, it seems plausible that very arcuate structures, such as the buried Apennine 
folds, may form by oroclinal bending driven by belt-parallel compression (i.e., secondary oroclines after [37]). Similar considerations have been made by other authors [38] [39] [40], concerning the formation of the Northern Apennines. On the other hand, it is not clear how the slab-retreat mechanism could explain such complex pattern of oroclinal arcs. For instance, numerical and laboratory experiments suggest that subduction-related forces need tens of millions of years to induce only a modest curvature of the subduction trench [41] [42].

5) When applied to the interpretation of the Neogene evolution of the central Mediterranean, the slab-retreat mechanism encounters several difficulties, exhaustively discussed by [43] and [44]. In particular, [44] suggest that the recent uplift pattern of the Apennine belt can hardly be explained as an effect of subduction-related processes.

6) Some aspects of the present velocity field of the Apennines, deduced by space geodetic measurements [45], are scarcely compatible with the implications of the slabretreat mechanism [39], as discussed later in this work.

7) Some authors [46] [47] have applied the slab retreat mechanism to the EoceneOligocene evolution of the Western Alps. However, [48] suggest that this mechanism cannot be invoked to explain the tectono-metamorphic evolution of the above belt, with particular reference to the exhumation of eclogite complexes.

A different interpretation for the evolution of the Apennine belt has been proposed by other authors [38] [39] [40] [43] [49] [50] [51], who suggest that the observed tectonic pattern is due to the kinematics of the confining plates (Africa, Iberia, Adria and Eurasia). In the next section, an updated description is provided about how the above boundary conditions have determined the post Middle Miocene evolution of the Adriatic plate and surrounding belts, with particular regard to the northwestern protuberance of that plate that now lies below the Padanian area.

As concerns the tectonic setting in the Western Alps and the occurrence of major earthquakes in the Ligurian sea and in the western Swiss Alps (Figure 2), most of the geodynamic interpretations so far proposed [52]-[57], invoke a poorly defined counterclockwise rotation of the northern Adriatic domain as the main driving mechanism. However, this hypothesis does not explain how the proposed behaviour of the northern Adria domain can be reconciled with other evidence about the kinematics of the Adria plate [39]. In this work, the deformation pattern of the Western Alps and the peculiar distribution of seismic activity are explained as an effect of redistribution of orogenic masses that accommodates the convergence of the Adria, Iberia and Eurasia plates.

Since the understanding of the present tectonic setting in the study area may be considerably favoured by the knowledge of the recent evolution, the next section reports a synthetic description of such information, which has been inferred from the analysis of a huge amount of evidence.

\section{Post Middle Miocene Evolution of the Adriatic Plate and Surrounding Belts}

A long study of the observed deformation pattern in the central Mediterranean region 
and the search of the geodynamic/tectonic context that may best account for the huge amount of evidence now available [1] [38] [43]-[51] [58] [59] [60] [61] [62] led us to propose the evolutionary reconstruction shown in Figure 3. This interpretation suggests that tectonic activity in the central Mediterranean region has been driven by
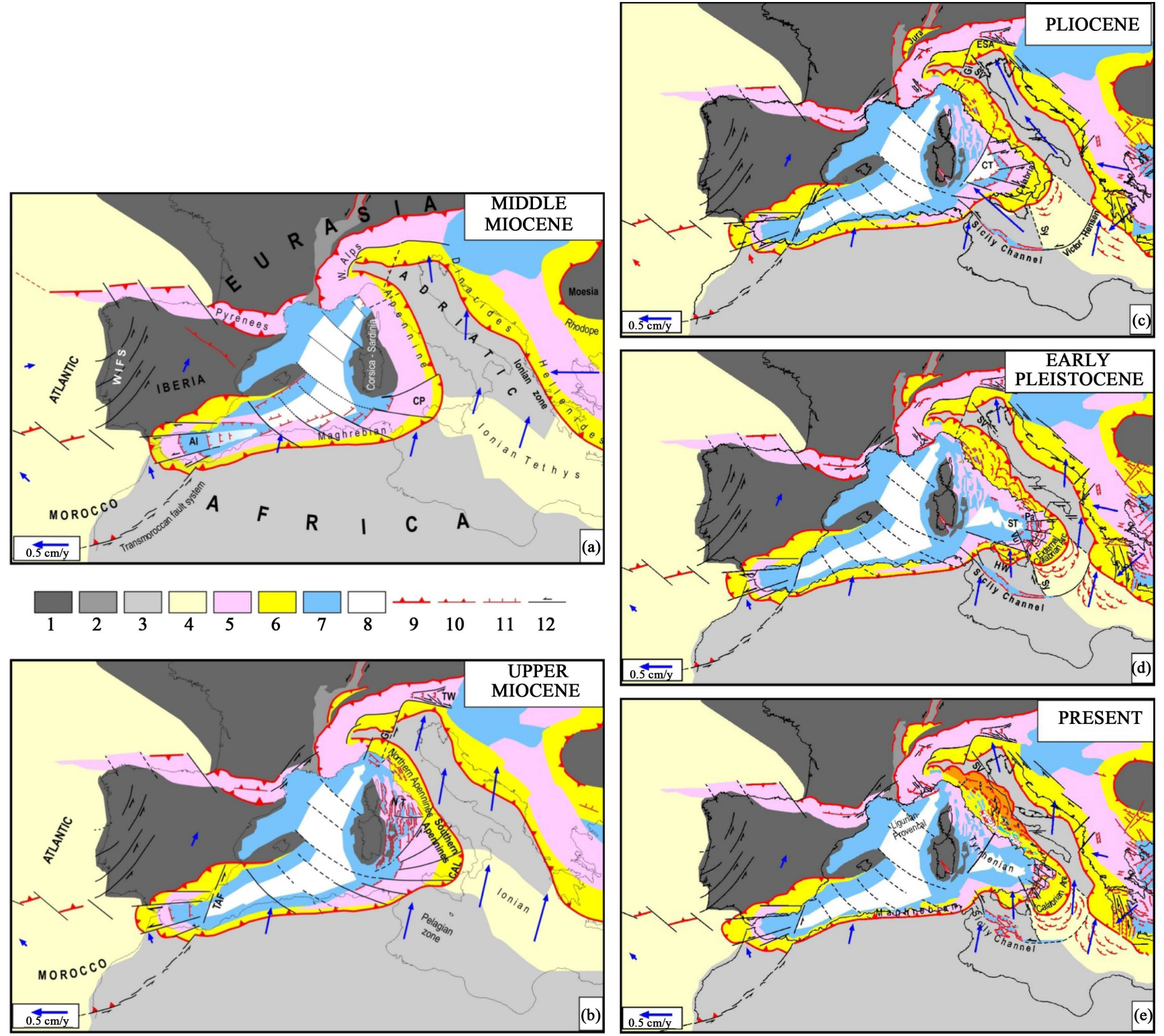

Figure 3. Evolutionary reconstruction of the central Mediterranean region proposed by Mantovani et al. [38] [43] (a) Middle Miocene. $\mathrm{Al}=$ Alboran basin, $\mathrm{CP}=$ Calabria-Peloritani (b) Upper Miocene. $\mathrm{CAL}=$ Calabria, $\mathrm{Gi}=$ Giudicarie fault system, $\mathrm{NT}=\mathrm{Northern}$ Tyrrhenian basin, TAF = Transalboran fault system, TW = Tauern window (c) Pliocene. CT = Central Tyrrhenian $($ Magnaghi and Vavilov basins), ESA = Eastern Southern Alps, SV = Schio-Vicenza fault system, Sy = Syracuse escarpment (d) Early Pleistocene. HW = Hyblean wedge, $\mathrm{Pa}=$ Palinuro fault, $\mathrm{ST}=$ Southern Tyrrhenian (Marsili basin), Vu = Vulcano fault (e) Present. 1) European continental domain 2) Cenozoic Rift system 3) Africa-Adriatic continental domain 4) Oceanic domains 5) Alpine belts 6) Neogene accretion belts 7 , 8) Neogene extensional basins and oceanized zones 9) External fronts of orogenic belts 10, 11, 12) Major compressional, extensional and transcurrent tectonic features. Thin lines identify the present geographical contours. Blue arrows indicate plate motions with respect to Eurasia [38] [43] [51]. 
the convergence of the confining plates and that the spatio-temporal distribution of deformation has been controlled by the need of minimizing the resistance of gravitational and frictional forces, in line with the minimum action principle [63] [64] [65] [66]. Most often, this condition has been fulfilled by the consumption of the least buoyant lithosphere, mainly represented by the Tethyan oceanic domain.

The evolutionary reconstruction given in Figure 3 relates to the period during which major discontinuities have been activated in the northern Adriatic domain. In the middle Miocene (Figure 3(a)), the Adriatic promontory, still closely connected with the African plate, was moving roughly NNW ward. Due to previous tectonic events, the northwestern part of this promontory was characterized by an old discontinuity (the Giudicarie fault system), which originally formed as a transfer fault of the PeriAdriatic Lineament in the upper Cretaceous and lower Eocene and then, in the lower Oligocene, turned in a underthrusting zone [67] [68] [69].

In the geodynamic context that characterized the central Mediterranean region in the middle Miocene (Figure 3(a)), the minimum action principle required the Adriatic promontory to decouple from its northwestern protuberance (which was deeply embedded into the Western Alps) and start a roughly NNE ward motion (Figure 3(b)), at the expense of the structures that were present in the Carpatho-Pannonian area [38] [43]. Such decoupling was allowed by the reactivation, as a sinistral transpressional fault system, of the previous Giudicarie thrust zone [70] [71]. The separation between the western and eastern Padanian sectors at the Giudicarie discontinuity (and its presumed southwestward prosecution) has recently been suggested by [11] as well. The above interpretation is consistent with the fact that after the Giudicarie event accretion only occurred in the sector of the Alpine front which lay east of the Giudicarie fault system and the orientation of maximum shortening was perpendicular to the present thrust front in the Eastern Southern Alps [32] [69] [72].

Another major effect of the main Adria indenter, after the Giudicarie decoupling was the occurrence of an extrusion process in front of such indenter, involving the roughly eastward escape of an Alpine wedge, allowed by lateral transcurrent guides [73] [74] [75]. In the wake of the extruding wedge, extensional deformation took place, leading to the formation of the Tauern tectonic window (Figure 3(b)).

This phase lasted until the late Miocene, when the need of developing a more convenient complex of shortening processes (minimum action principle) required another major change of the kinematic/tectonic pattern in the central Mediterranean area [38] [43]. The above change was mainly determined by the fact that at the collision zone between the Anatolian Aegean-Balkan system (moving roughly westward) and Adria (moving roughly NNE ward) the low buoyant thinned continental domain (Ionian zone [76] had been completely consumed [77]. Indeed, such condition determined a strong increase of the forces that resisted the above plate convergence. This made convenient a drastic reorganization of the shortening processes in the whole central Mediterranean area that involved a number of major tectonic events. The main effect was the decoupling of the Adriatic-Ionian-Hyblean plate from Africa (Figure 3(c)), which was 
allowed by the activation of a major lithospheric discontinuity, formed by the Victor-Hensen and Sicily Channel strike-slip/transtensional fault sytems. To accommodate the roughly E-W shortening required by the convergence between the Adria-Ionian plate and the Northwestern Africa domain (Tunisia), the Hyblean wedge underwent a roughly NW ward extrusion (see, e.g. the numerical experiments described by [50]. The indentation of this extruding wedge then caused the outward escape of wedges from the Apennine-Alpine belt (which at that time lay to the east of Sardinia), at the expense of the thinned continental Adriatic margin and the oceanic Ionian domain (Figure 3(c)). The decoupling of the Hyblean wedge from the Adria-Ionian plate was allowed by transtensional and transcurrent tectonics at the Syracuse fault system [78] [79]. The proposed evolution can account for the present shape of the Alpine belt lying along the northern boundary of the Hyblean wedge [80] [81].

As argued by [38] [43], the above context can plausibly and coherently account for the complex spatio-temporal distribution of major tectonic events that almost simultaneously started in the late Miocene and then developed until the upper Pliocene in the central Mediterranean area (Figure 3(c)), as listed in the following:

-Activation of the Sicily Channel and Victor-Hensen fault systems in the Pelagian zone, which allowed the Adriatic plate (including the northern part of the Ionian zone) to decouple from Africa;

-Extensional activity in the central Tyrrhenian area, which led to the formation of the Magnaghi-Vavilov basin (Central Tyrrhenian);

-Acceleration of orogenic activity at the outer front of the Apennine belt, after a period of relative quiescence;

-Activation of a major strike-slip discontinuity in the northern Adriatic area, the Schio-Vicenza fault system;

-Formation of a system of dextral shear faults in the northern Dinaric region, which allowed the Adriatic plate to move roughly NE ward with respect to the Pannonian-Carpathian zone;

-Roughly northward displacement of the sector of the Maghrebian-Alpine belt which lay north of the Hyblean wedge.

The works that describe the tectonic events mentioned above and the supporting evidence are [38] [43] [49] [50] [51] [58] [62].

This evolutionary phase developed until the late Pliocene-early Pleistocene (Figure 3(d)), when the entering of thick Adriatic continental lithosphere at the Southern Apennines trench zone, induced such belt sector to stop or considerably slow down its lateral escape. Since then, the only sector of the belt that was allowed to escape laterally, being facing the remnant of the Ionian oceanic domain, was the Calabrian Arc. The extensional tectonic that developed in the wake of the escaping Calabrian wedge, bounded by the Palinuro and Vulcano strike-slip faults, caused the formation of the southernmost Tyrrhenian (Marsili basin), while accretionary activity occurred along the outer front of the wedge, with the formation of the External Calabrian Arc. In response to the belt parallel compression that drove such extrusion, the Calabrian wedge underwent 
rapid uplift and major fracturation [82] [83] that generated several transversal and belt parallel fault systems.

During the same evolutionary stage, the southern Adria sector, stressed by the roughly E-W convergence between the Balkan peninsula and Africa underwent upward flexure [84] [85] and was characterized by a very low mobility. The strengthening of tectonic activity along the eastern and the northern peri Adriatic zones since the middle Pleistocene (see the references given by [50]) indicates that the roughly northward motion of the Adria plate has accelerated since that time. This acceleration has considerably influenced tectonic activity in the Apennine belt, since the outer sector of that belt, stressed by Adria, has undergone belt parallel shortening, accommodated by the uplift and lateral escape of orogenic wedges, at the expense of the adjacent Adriatic domain (Figure 4).

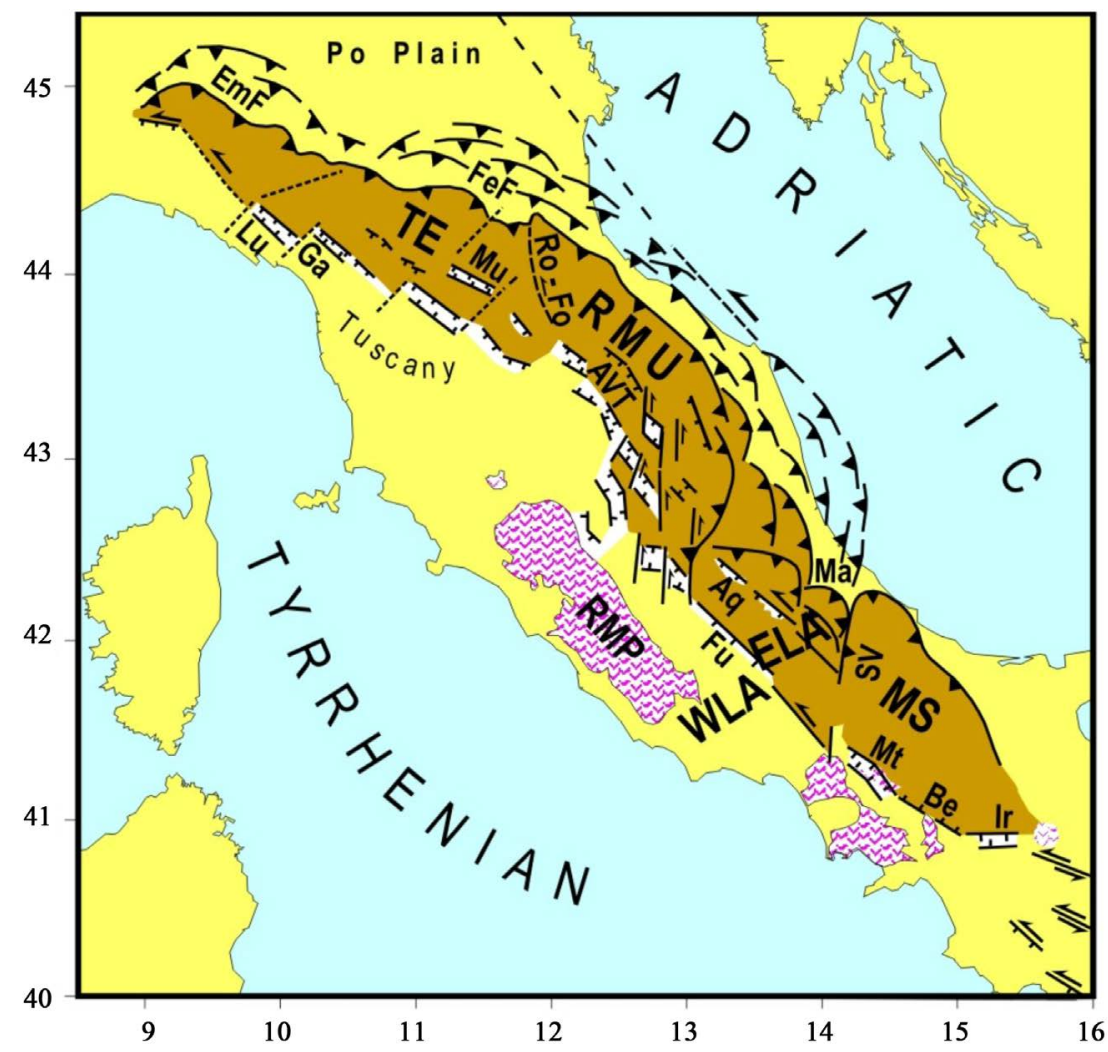

Figure 4. Tectonic sketch of the outer Apennine sector (dark brown) that, stressed by the Adriatic plate has undergone belt-parallel shortening (accommodated by uplift and lateral escape) since the middle Pleistocene. Extensional and transtensional fault systems mark the decoupling zone between the outward extruding wedges and the inner, almost fixed, part of the Apennine chain. $\mathrm{Aq}=$ Aquila fault system, $\mathrm{AVT}=$ Alta Valtiberina trough; $\mathrm{Be}=$ Benevento fault system, ELA = eastern portion of the Lazio-Abruzzi carbonate platform, Ro-Fo = Romagna-Forli seismic belt, $\mathrm{Fu}=$ Fucino fault system, $\mathrm{Ga}=$ Garfagnana trough, $\mathrm{Lu}=$ Lunigiana trough, $\mathrm{Ir}=$ Irpinia fault system, $\mathrm{Ma}=$ Maiella, $\mathrm{Mt}=$ Matese fault system, $\mathrm{MS}=$ Molise-Sannio wedge, $\mathrm{Mu}=$ Mugello trough, EmF, FeF = Emilia and Ferrara buried folds, RMP = Roman Magmatic Province, RMU = Romagna-Marche-Umbria wedge, SV = Sangro-Volturno thrust front, TE = ToscanaEmilia wedge, WLA = western portion of the Lazio-Abruzzi platform. Symbols as in Figure 1. 
The mobile belt was formed by the Molise-Sannio wedge (MS), in the Southern Apennines, the eastern sector of the Lazio-Abruzzi carbonate platform (ELA), in the Central Apennines, and the Romagna-Marche-Umbria (RMU) e Toscana-Emilia (TE) wedges, in the Northern Apennines (Figure 4). The tectonic mechanism that determined such context has been influenced by some structural and tectonic features of the Apennine belt [43] [50], described in the following:

-In some sectors of the Apennine belt the coupling between the sedimentary cover and their basement was weak for the presence of a layer of Triassic evaporites (Burano formation), characterized by low mechanical resistance due to the presence of soft anydhrite levels among stiffier dolostones [86] [87] [88] [89]. This feature, favouring the decoupling between the cover and the basement, considerably influenced the minimum action condition in the Apennine belt, making more convenient the lateral escape of wedges with respect to other shortening mechanisms.

-Thrusting developed in the outer front of the extruding wedges, while extensional/ transtensional deformation occurred in the inner side of wedges, generating a series of troughs, now located in the axial zone of the belt [34] [35] [36] [90]-[95].

-Since the early Pleistocene, intense volcanic activity has occurred along the inner side of the Romagna Marche-Umbria wedge [96], building up the Roman volcanic province (Figure 4). This phenomenon has been interpreted as an effect of transtensional tectonics [97].

-Another significant effect of the belt-parallel shortening is the uplift of the mobile belt [34] [98]-[107].

Since the late Pleistocene (Figure 3(e)), the relative motion of the Adria-Ionian plate with respect to Africa has undergone a considerable slowdown, due to the increasing resistance to shortening along the surrounding buoyant orogenic structures (Hellenides, Dinarides, Alps and Apennines). This trend suggests that at present the motion of Africa cannot be significantly different from that of southern Adria.

Since the late Miocene, the Padanian zone has undergone a compressional strain regime, due to the oblique convergence between Iberia, Adria and Eurasia plates (Figure $3)$.

\section{Main Discontinuities in the Northern Adriatic Foreland and Their Possible Role in the Ongoing Seismotectonic Pattern}

The evolution described in the previous section involves the development of two major discontinuities in the northern Adriatic foreland (Figure 3). In this section, we describe with greater detail the main features of such fault systems and, in particular, the role that they can play in the ongoing seismotectonic setting of the Padanian area. To better explain the above features, Figure 5 reports a tentative perspective view of the Adriatic foreland in some key evolutionary phases.

The proposed reconstruction suggests that after the reactivation of the Giudicarie discontinuity as a left-lateral fault system, the Adriatic promontory underwent a roughly NE to NNE ward displacement (Figure 3(b) and Figure 5(b)). Since the deepest 

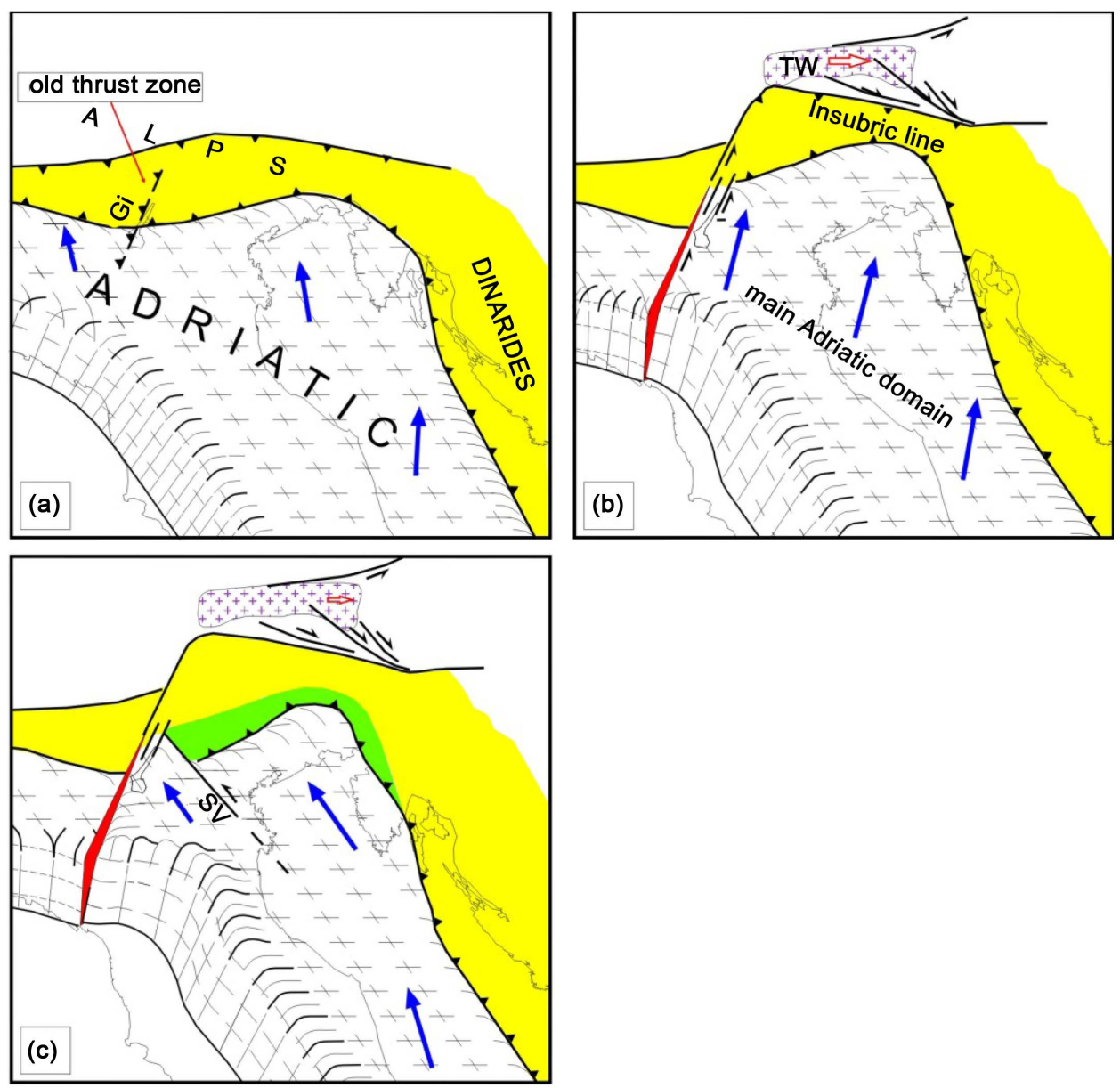

Figure 5. Tentative reconstruction of the geodynamic/tectonic setting that led to the reactivation of two major discontinuities in the northern Adriatic foreland. (a) Middle Miocene: the Adriatic/ African promontory moves roughly NNW ward (blue arrows), causing thrust activity along the entire Alpine belt. The Giudicarie lineament (Gi) is an old thrust zone, inactive during this phase; (b) Upper Miocene: the Giudicarie discontinuity reactivates as a left-lateral transpressional fault system, allowing the main Adria domain to decouple from its northwestern protuberance, embedded in the Western Alps, and to undergo a new kinematic pattern. TW = Tauern window (see Figure 3(b)); (c) Pliocene-Quaternary: the Adria domain, not anymore connected with Africa (Figure 3), moves roughly NNW ward. In the northern Adriatic domain, this kinematic change required the reactivation, as a left-lateral fault system, of an old discontinuity (SchioVicenza). Since the beginning of this tectonic phase, the Giudicarie discontinuity has become a thrust zone, where the mobile Adria domain underthrusts the westernmost Adria protuberance. The green indicates the accretionary belt that formed along the norther front of the Adria plate.

subducted Adriatic margin, being embedded into the Tyrrhenian mantle, could not move as the shallow Adria domain, it is reasonable to suppose that during this phase the dip of the slab underwent a reduction, as tentatively shown in Figure 6.

This hypothesis may explain why the dip of the buried Adriatic foreland is higher in the Padanian zone lying east of the Giudicarie fault than in the area located west of the above discontinuity, as documented by seismo-geological cross sections (Figure 7). This hypothesis can also explain why the thickest sedimentary deposits in the 


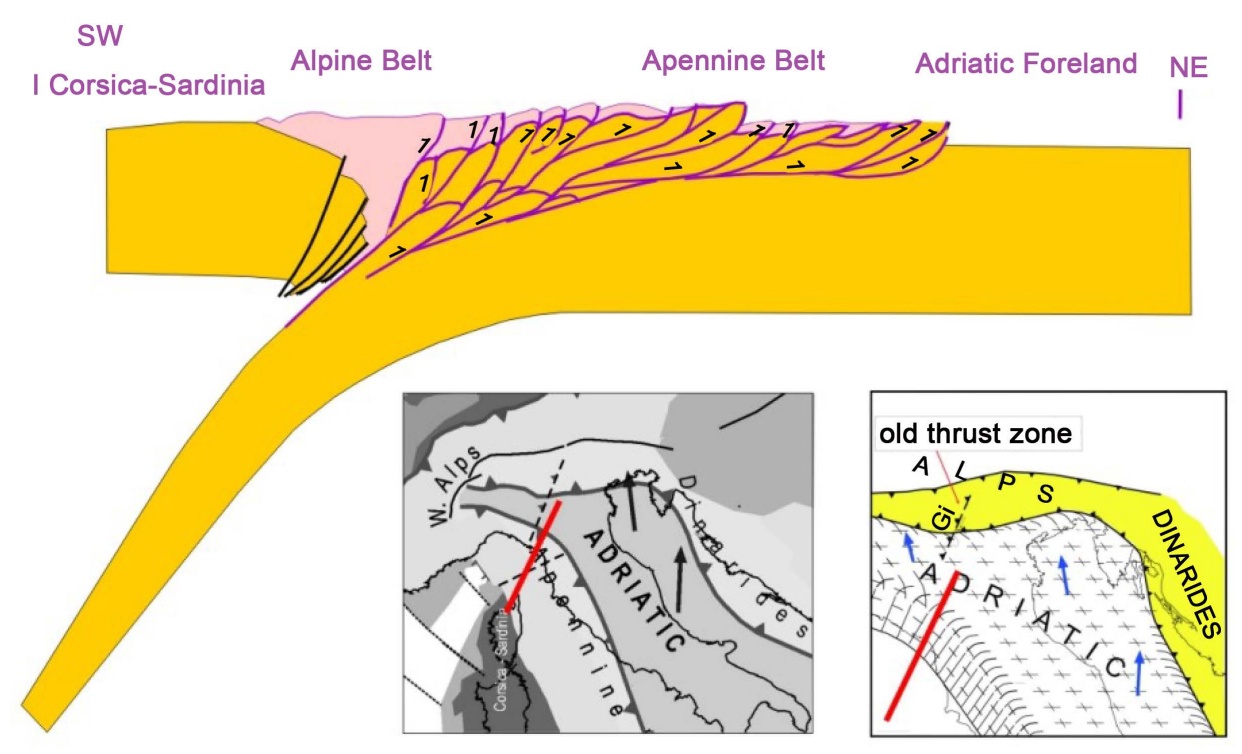

(a)

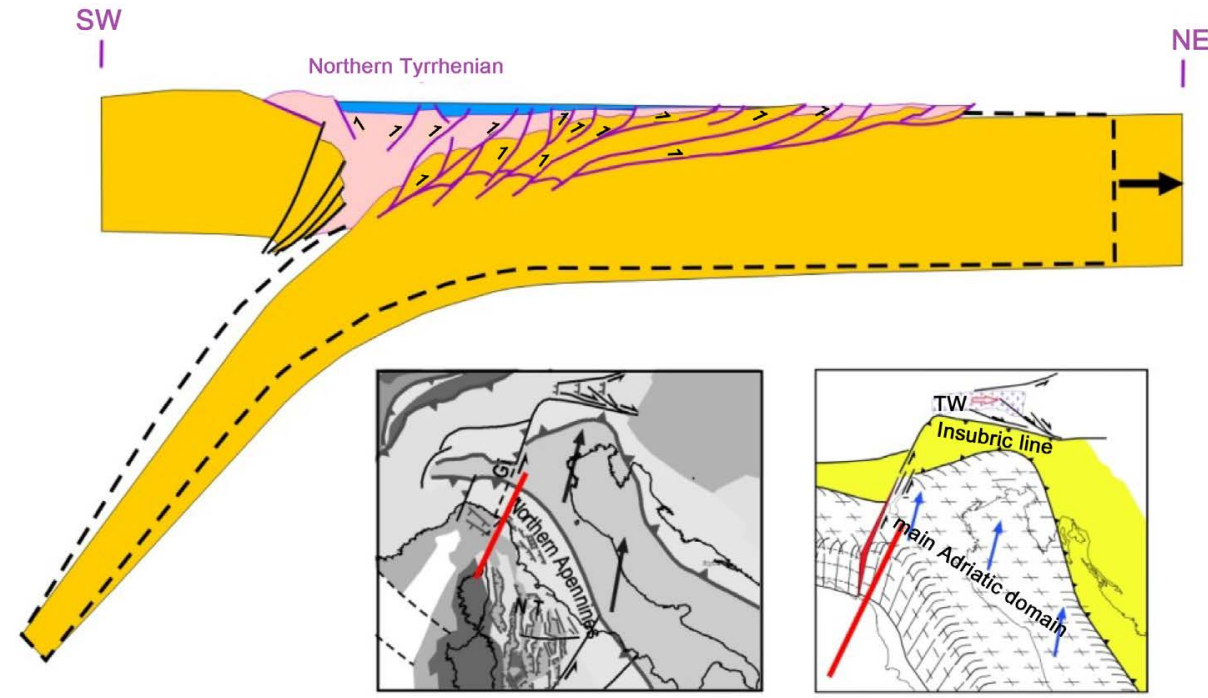

(b)

Figure 6. Tentative reconstruction of the unbending that the Adriatic slab is supposed to have undergone in response to the NE ward displacement of its shallow domain (Adria plate), which was allowed by the activation of the Giudicarie decoupling fault system (see maps). (a) Middle Miocene configuration along the section traced in the map; (b) Upper Miocene, The NE to NNE ward displacement of the shallow Adria plate and the very low mobility of its subducted part causes a reduction of the dip of the slab. As an effect of this process, the Adriatic foreland laying to the east of the Giudicarie fault underwent lowering, creating a step with respect to the Adriatic domain situated west of that fault (see the perspective image).

pedeApennine foredeep are located to the east of the Giudicarie discontinuity (Figure 1).

The presence of a steeper eastern Adriatic foreland, underlying the Emilia Plain, with respect to the western Adriatic foreland (underlying the Lombardia plain) has been suggested by other authors as well [14]. Furthermore, different structural settings in the 
(a)
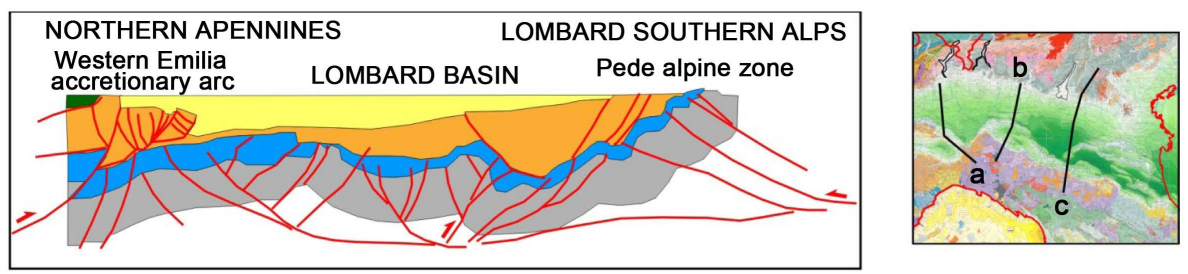

(b)
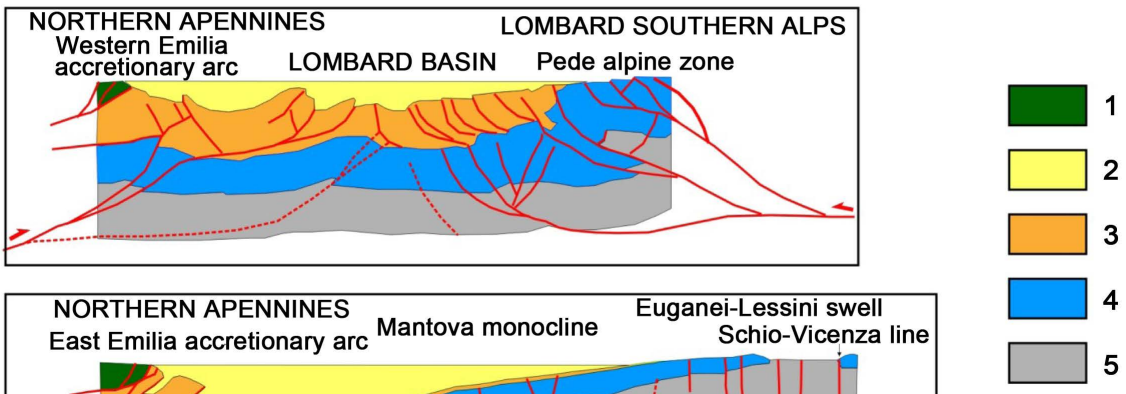

(c)

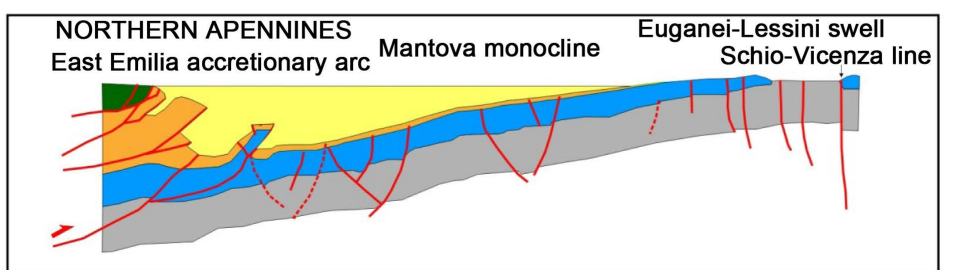

Figure 7. Seismo-geological sections in the Padanian region, traces in the inset [8]. 1) Ligurian units, 2) Plio-Pleistocene units, 3) Cenozoic (pre-Pliocene) units, 4) Mesozoic units, 5) Paleozoic basement.

eastern and western Padanian sectors are evidenced by seismo-geological sections which indicate the Giudicarie discontinuity as a possible boundary between the differentiated settings [11] [12].

The fractures of the Adriatic foreland that can mainly influence the present seismotectonic activity in the study area have developed since the late Miocene (Figure $5(c)$ ), in response to the activation of the Schio-Vicenza left-lateral fault system. After that event, the roughly northward motion of the main Adriatic plate (lying east of that discontinuity) has been accommodated by thrusting in the Eastern Southern Alps. Shortening in the zone lying west of the Schio-Vicenza fault has been instead accommodated by different processes, mainly involving foreland structures. For instance, one may suppose that the Giudicarie discontinuity reassumed its old role of thrust zone, as tentatively illustrated in Figure 5(c). Such kind of process implies subsidence of the underthrusting eastern Adria domain and uplift of the western Adria foreland. The presumed underthrusting at the Giudicarie discontinuity is compatible with the structural setting pointed out by the seismo-geological sections [108] which indicate postMessinian activity roughly oriented E-W thrusts at the northernmost sector of that discontinuity.

Another major effect of the roughly SE-NW shortening that the Adriatic domain (including its subducted margin) has undergone during the post-Messinian phase, may be given by uplift of its most curved sector, as tentatively reconstructed in Figure 5(c). This hypothesis could explain a peculiar feature of the recent evolution of the Romagna Apennines, i.e. the belt sector which most probably overlay the above mentioned up- 
lifting sector of the Adria slab. As shown in the seismo-geological section given in Figure 8, the Romagna Apennines have undergone a remarkable uplift since the Pliocene [100]. This effect is clearly evidenced by the broad antiformal doming of the Romagna Apennines (Figure 8) and by the fact that in this belt sector the Ligurian units are almost absent [33] [34], a feature that is generally imputed to intense erosion of uplifted rocks.

\section{Present Seismotectonic Setting in the Northernmost Apennines and Related Buried Folds under the Po Valley}

In the previous sections and the cited papers, it has been suggested that since the middle Quaternary tectonic activity in the Northern Apennines has been driven by belt-parallel compression in the outer side of the chain (Figure 3). In this chapter, we provide a more detailed description of the tectonic processes that are supposed to have accommodated the proposed shortening in the Northern Apennines. The main geological, tectonic and morphological features that have been generated by the above driving mechanism are shown in Figure 1. The configuration of the mountain crests (Figure 1) helps to identify the structural elements that have undergone the most intense oroclinal bending and uplift. This evidence may be used to recognize the mecha-

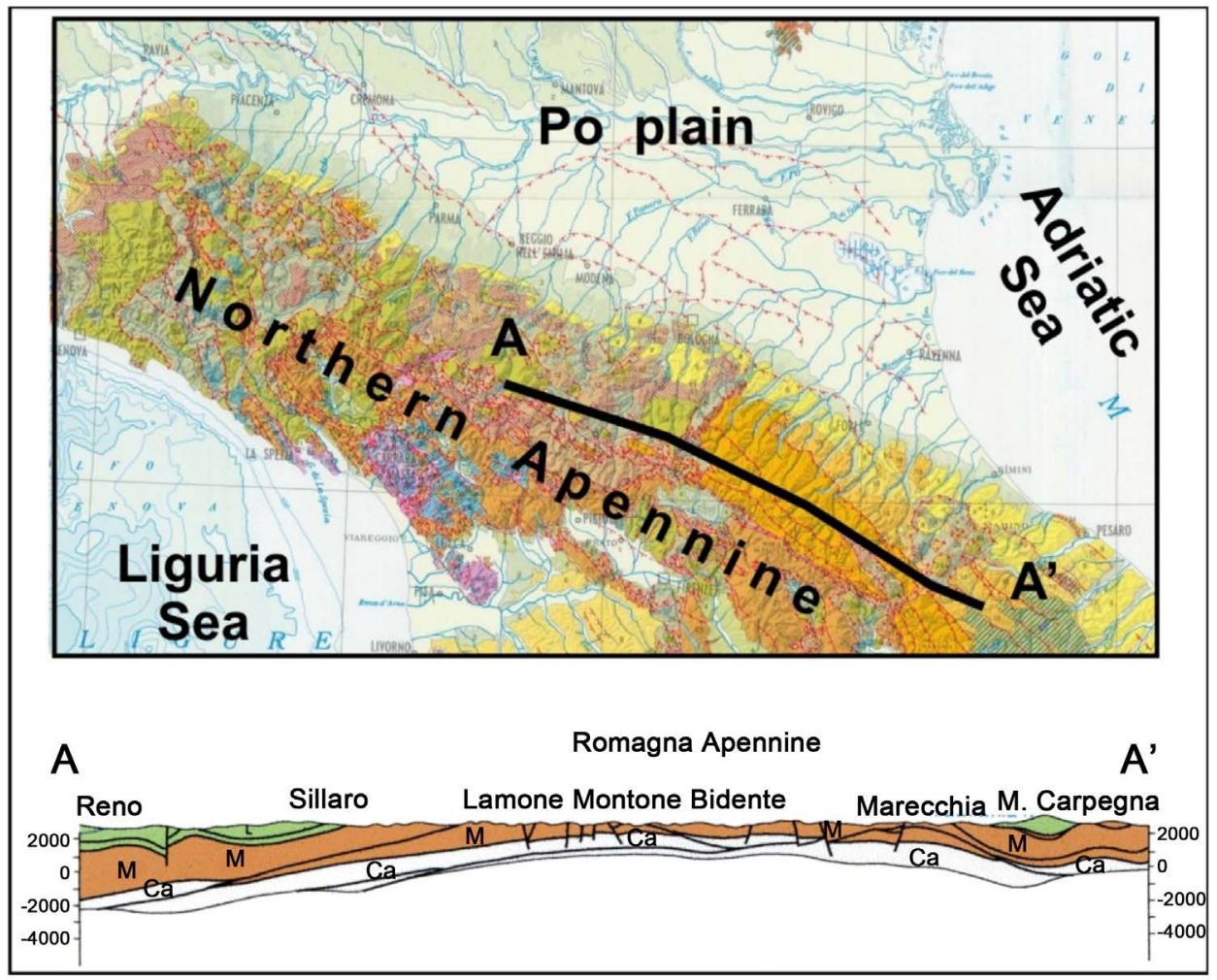

Figure 8. Seismo-geological cross section through the Romagna Apennines, evidencing the upward flexure of the layers and the lack of the top Ligurian units (L, green) in the central sector, which have presumably been eroded (After [34]). Ca = Mesozoic-Cenozoic carbonatic succession, $\mathrm{M}=$ Miocene foredeep tubidites. The trace of the section is reported in the map [109]. 
nism that has generated the troughs (Garfagnana, Lunigiana, Mugello, Casentino, AltaValtiberina) that correspond to the main seismic sources in that Apennine zone [60] [110] [111]. In this regard, we argue that the extensional regimes that led to the formation of the above troughs were induced by local divergence between morphological crests which, in response to belt-parallel compression, have undergone different bending patterns [41] [59] [60]. This interpretation is compatible with the fact that the cited troughs are just located along the internal side of the ridges (Figure 1) that show the most pronounced curvature. One could also note that such curved ridges belong to belt sectors not covered by Ligurian units, an effect that reveals enhanced erosion due to intense uplift.

The fact that the bending of ridges has not developed beyond the Lunigiana zone may be connected with the presence of almost fixed structures, such as the Ligurian Apennines and in particular the Ligurian Alps, in the northernmost edge of the belt. In particular, the low mobility of the Ligurian Alps is due to the fact that such structure is closely connected with its basement, since the basis of the sedimentary cover does not include significant late Triassic anydhrite levels [86] [87] [112] [113]. The above interpretation is corroborated by the fact that the Ligurian Apennines are the less deformed and uplifted structure in the Northern Apennines, as testified by the evidence that such sector of the belt is still covered by thick Ligurian units and does not include Quaternary extensional troughs [114].

The effects of the longitudinal shortening can be as well recognized (even if less evident) in the Padanian side of the belt, the one characterized by the lowest altitude. As argued earlier, the intense uplift (and consequent erosion) that has affected the eastern segment of this sector, the Romagna Apennines (Figure 8), may be explained as an effect of the peculiar deformation of the underlying Adriatic lithosphere (Figure 5(c)).

The fact that major earthquakes have occurred along a relatively narrow roughly S-N belt in the Romagna Apennines and Forlì zone (Figure 2) implies the presence of a major fault system. Since such discontinuity is most probably very young, its long-term geological effects are still poorly recognizable. The features that could have been generated by the above discontinuity may be represented by a series of faults that cuts the thrust fronts formed during the previous Miocene and Pliocene compressional phases [35] [100] [115] [116] [117]. Considering the proposed Quaternary tectonic context in the Northern Apennines (Figure 1), one could suppose that the above fault system has allowed the decoupling between the belt segments that are mostly parallel to the Adria plate (Umbria-Marche Apennines) and the segment (Emilia-Romagna Apennines) that, being oriented roughly $\mathrm{E}-\mathrm{W}$, opposes a stronger resistance to move as the driving Adria plate.

Another evidence of belt-parallel shortening in the Emilian Apennines is given by the presence of some transversal lineaments [118] [119] interpreted as thrust fronts by some authors [33] [34]. The Sillaro thrust front (Figure 1 and Figure 8) is generally recognized as the zone where the outcropping Miocene foredeep turbiditic units in the Romagna Apennines underthrust the Ligurian units of the Emilia Apennines [34]. In 
this sector, the belt-parallel shortening may also be accommodated by the bending and lateral escape of the Bologna wedge. This hypothesis is suggested by the outward curvature of that wedge, with respect to the adjacent sectors of the belt. This interpretation could explain why the main earthquakes in the Bologna zone are mostly distributed along the outer front of that wedge (Figure 9).

In the westernmost sector of the Emilia Apennines it is possible to recognize a structure that is hereafter recalled as the Piacenza wedge (Figure 1). Stressed by belt-parallel compression and resisted by the almost fixed structures of the Ligurian Apennines and Alps, this wedge has undergone a roughly Northward lateral escape. The decoupling of the above wedge from the Ligurian Apennines is allowed by sinistral shear at the Bedonia-Varzi fault system [36], where seismic activity occurs (Figure 1 and Figure 2). The shape of the Emilia folds buried beneath the Po Valley [120] [121] is compatible with the indentation of the Piacenza wedge. The roughly S-N extensional tectonics recognized at the E-W oriented Villarvernia-Varzi fault system [122] [123] [124] might results from the separation of the Piacenza wedge, moving roughly Northward, from the almost fixed Ligurian Apennines (Figure 1). A decoupling between the Piacenza wedge and the eastern segment of the Emilia Apennines could be allowed by transpressional deformations at the Enza-Taro transversal fault system [34] [36] [125] [126].

As concerns the possible connection between tectonic and seismic activity, one could remark that after the activation of the Villarvernia-Varzi fault system in $1828(M=5.8)$, revealing a roughly northward motion of the Piacenza wedge, major shocks occurred along the northeastern border (Reggio-Emilia zone, $1831 \mathrm{M}=5.5$ e $1832 \mathrm{M}=5.5$ ) and the inner boundary (Lunigiana, $1834 \mathrm{M}=5.8$, Garfagnana, $1837 \mathrm{M}=5.8$ ) of that wedge.

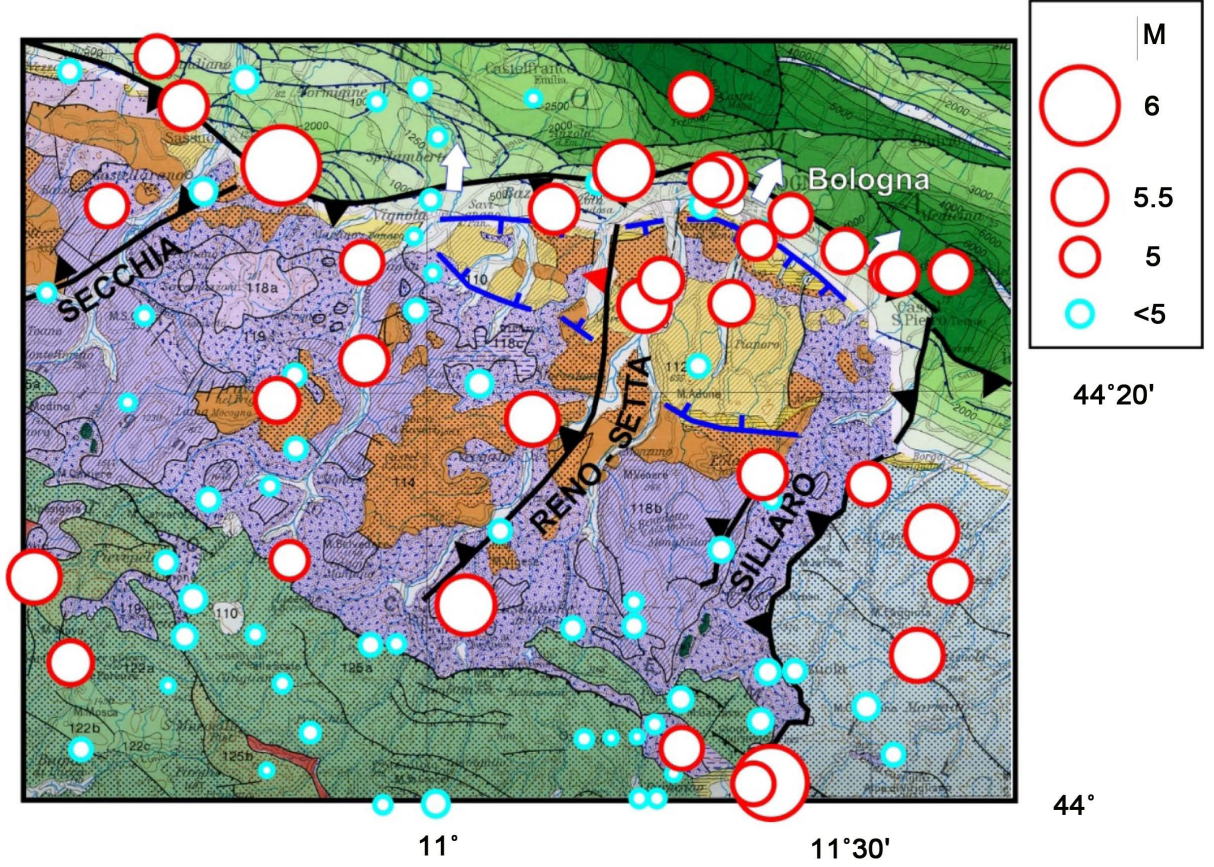

Figure 9. Tectonic sketch of the Bologna Apennines and major earthquakes occurred since 1000 A.D. [16]. Symbols as in Figure 1 and Figure 2. 
The outer Apennine folds buried beneath the Po Valley undergo the same stresses that act on the emerged part of the belt (Figure 10). This hypothesis is confirmed by the fact that the above structures have been affected by significant seismicity: Emilia folds $(1438 \mathrm{M}=5.6,1501 \mathrm{M}=6.0,1505 \mathrm{M}=5.6,1831 \mathrm{M}=5.5,1832 \mathrm{M}=5.6,1971 \mathrm{M}=$ 5.6); Ferrara folds (1346 M =4.9, $1570 \mathrm{M}=5.5,1624 \mathrm{M}=5.5,1796 \mathrm{M}=5.6,1996 \mathrm{M}=$ $5.4,2012 \mathrm{M}=5.8,5.9)$; Adriatic folds $(1672 \mathrm{M}=5.6,1786 \mathrm{M}=5.6,1875 \mathrm{M}=5.9,1916$ $\mathrm{M}=6.0,6.1)$.

Another possible connection between seismic activations of tectonically connected fault systems could have determined the fact that the May 2012 earthquakes in the Emilia folds (Figure 10) have been preceded in the January of the same year by earthquakes that might be located along the presumed Giudicarie discontinuity at depths of about $30 \mathrm{~km}$ below the Parma area $(\mathrm{M}=4.9)$ and about $60 \mathrm{~km}$ below the Lunigiana area $(M=5.4)$. This presumed connection could be due to the fact that an activation of the Giudicarie thrusting zone, may allow a roughly westward acceleration of the Adriatic foreland, which on its turn may favour an increase of compressional stress (and related seismic activity) in the Ferrara buried folds [59] [60] [61]. The connection of seismic activity below the Lunigiana zone and the activation of the Giudicarie discontinuity is also compatible with the fact that the strong earthquake that hit the Verona area in 1117 (possibly located in the northernmost sector of the Giudicarie fault) was accompanied, in the same day, by an earthquake felt with an intensity of VIII in the above Tuscany zone [127].

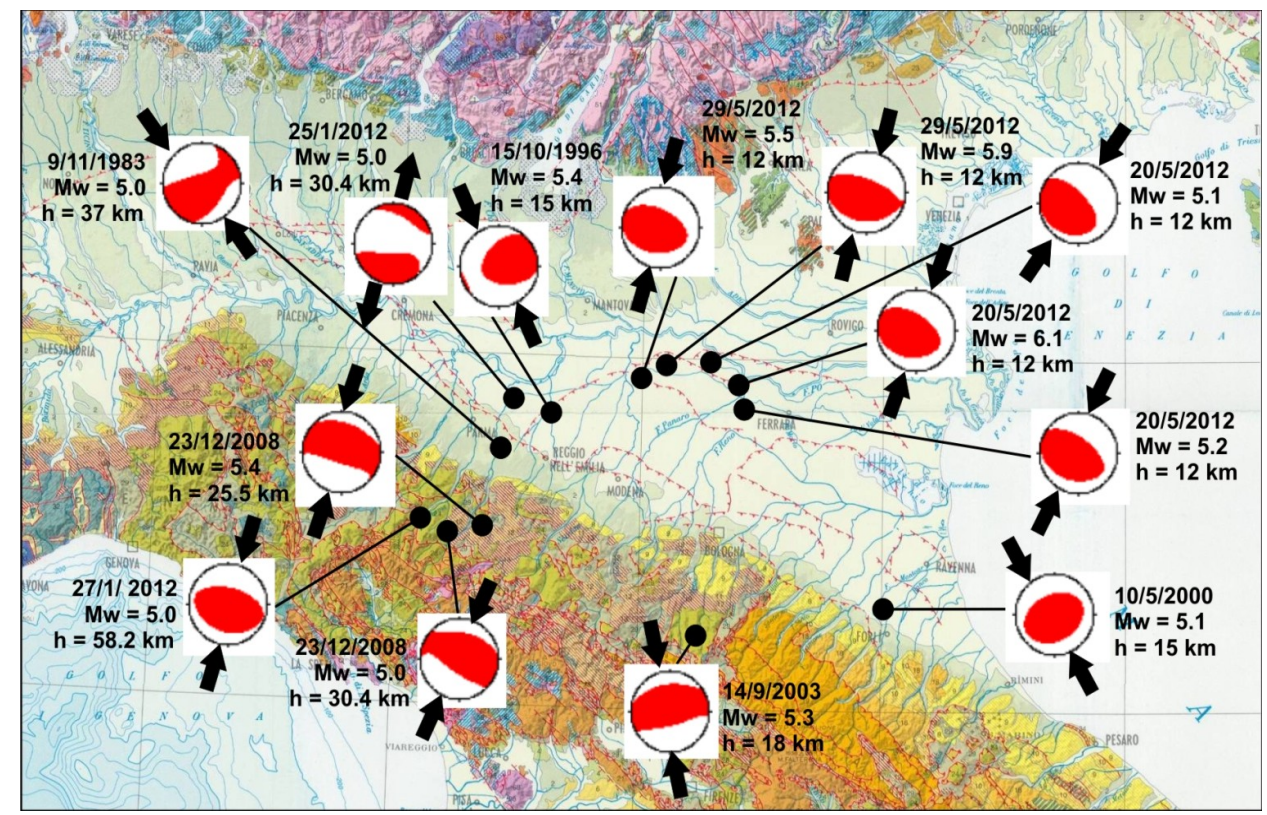

Figure 10. Focal mechanisms of earthquakes that occurred in in the PedeApennine Padanian zone since 1980 ( $\mathrm{Mw} \geq 5$ ), reported on the Geological Map of Italy [109]. Mw is the moment magnitude, $\mathrm{h}$ is the hypocentral depth. The black converging arrows indicate the direction of the maximum horizontal shortening axis. Data from the Centroid Moment Tensor Catalogue (www.globalcmt.org). 


\section{Present Seismotectonic Setting in the Western Padanian Region and Western Alps}

We argue that seismotectonic activity in these regions is related to the redistribution of orogenic material that accommodates the shortening required by motions of the Iberia and Adria plates with respect to Eurasia (Figure 11). The evidence and arguments that support the proposed plate kinematics and the evolutionary pattern that has led to the present context are described in a number of works [1] [39] [43] [51] [62]. This interpretation (Figure 11) suggests that the Iberian microplate moves independently from the Africa and Eurasia. The decoupling between Iberia and Africa is accommodated by sinistral transpressional movements at the Transalboran fault system and by the roughly westward escape of the Alboran wedge [128] [129]. The decoupling of Iberia from the Atlantic-Eurasia plate is accommodated by a complex of sinistral transpressional faults in the Portugal-Northwestern Spain zone [130] [131]. The convergence between Iberia and Eurasia is accommodated by a variety of shortening processes in a wide region, including the Pyrenean belt, the Southeastern France and the Western Alps, as described below.

Tectonic activity in the Pyrenean belt is indicated by the earthquakes and deformation that affect several reverse faults [132] [133]. In front of the eastern Pyrenean belt, the Montagne Noire massif and surroundings have been affected by significant uplift in the Quaternary [134] [135] [136].

The evolutionary reconstruction proposed by [62] implies that since the Oligocene the NE-SW Iberia-Eurasia convergence has induced a roughly NE-directed compressional stress regime in France and the western Alpine region [137] [138]. In the most recent evolutionary phase, considerable uplift, widespread volcanism and seismic ac-

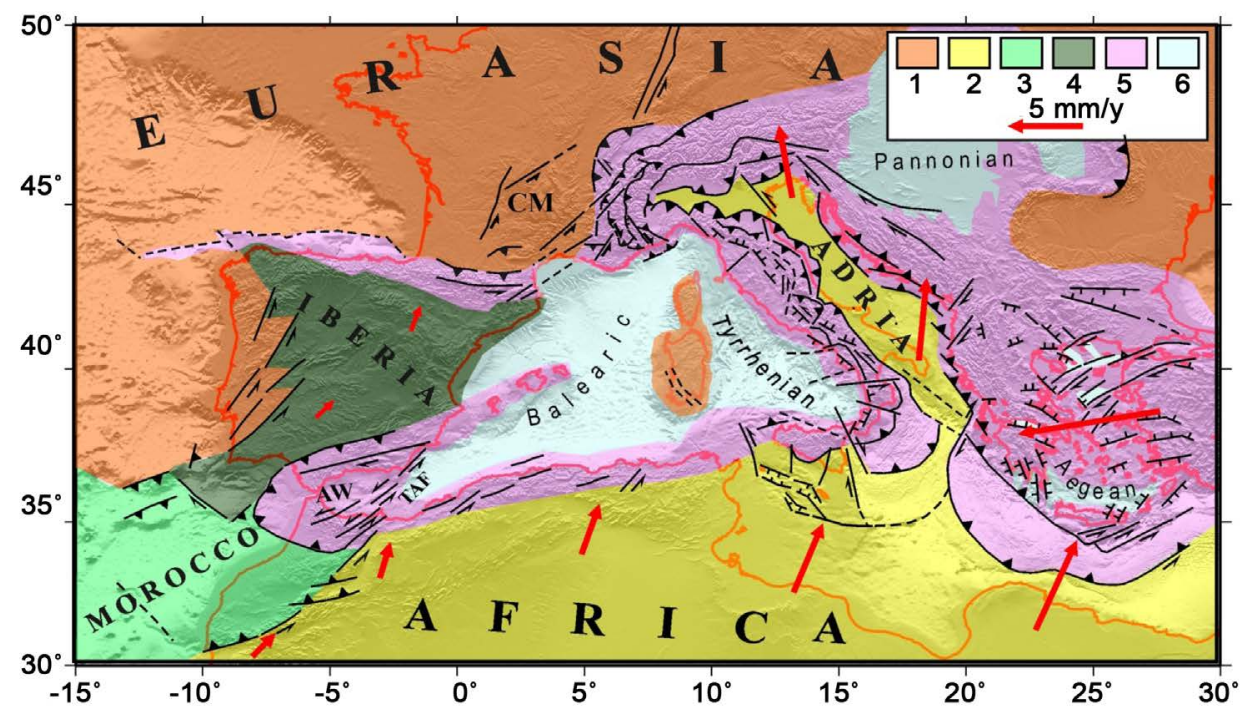

Figure 11. Kinematics of the Africa, Iberia and Adria plates with respect to Eurasia [1] [39] [51] [64] that determines the compressional regime in the study area. 1) Eurasian domain 2) AfricaAdriatic domain 3) Morocco plate 4) Iberian plate 5) Orogenic belts 6) Main extensional basins. $\mathrm{AW}=$ Alboran wedge, $\mathrm{TAF}=$ Transalboran fault system, $\mathrm{CM}=$ Central Massif. 
tivity is recognized in the Central Massif [139] [140] [141] [142]. Moreover, several tectonic lineaments in Languedoc and Provence have been interpreted as effects of recent activity [143]-[149]. Such lineaments (Figure 12) are mostly represented by E-W thrusts (e.g. the Ventoux, Luberon and Trevaresse faults) and NE-SW strike-slip structures (e.g. the Cevennes, Nimes and Middle Durance faults).

Although in the above zones the rate of active deformation seems to be quite low [146], some strong shocks are well documented, as the 1909 Lambesc earthquake ( $\mathrm{I}=$ IX, $M=6,[152])$. Furthermore, the significant seismic damage of the Roman acqueduct

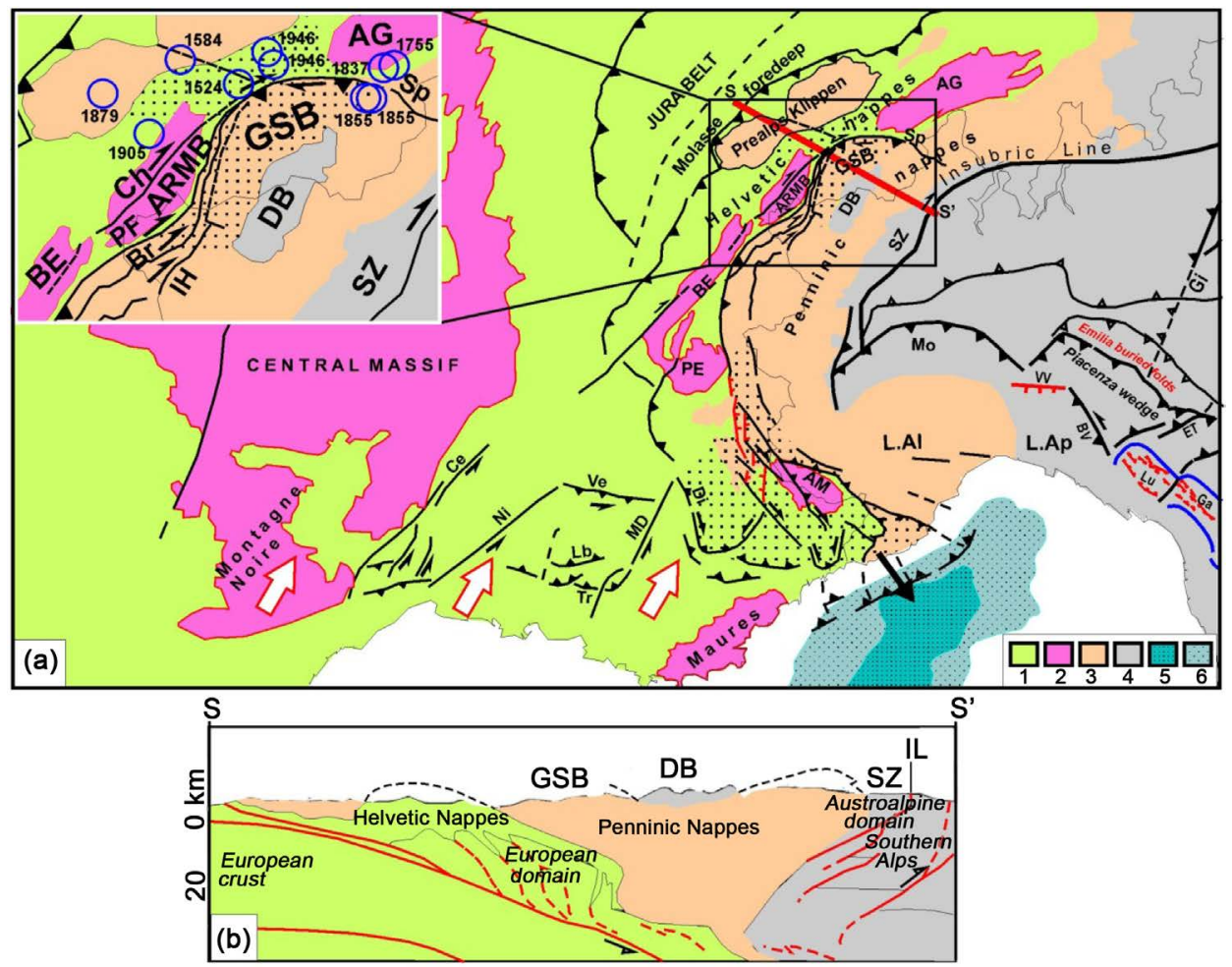

Figure 12. (a) Tectonic sketch of the Western Alps and surroundings, evidencing the zones (dotted) where compressional stresses induce uplift and extrusion of orogenic material. The empty arrows indicate the NNE ward push of Africa, transmitted by Iberia and the France foreland. The large black arrow in the Southwestern Alps indicates the trend of the escaping wedge. 1) European domain 2) Hercynian Massifs: $A G=$ Aar-Gotthard, $A M=$ ArgenteraMercantour, $\mathrm{ARMB}=$ Aiguilles Rouges-Mont Blanc, $\mathrm{BE}=$ Belledonne, $\mathrm{PE}=$ Pelvoux 3) Orogenic belts derived from the closure of the Alpine Tethys domain 4) Adriatic-Apennine domain 5,6) Very thinned and thinned areas in the Ligurian basin, respectively. The red line in the northwestern Alps is the trace of the cross section reported in $\mathrm{B} . \mathrm{Br}=$ Brianconnais Front, $\mathrm{Ce}=$ Cevennes fault, $\mathrm{Ch}=$ Chamonix Line, $\mathrm{DB}=$ Dent Blanche, $\mathrm{Di}=\mathrm{GSB}=$ Grand Saint Bernard Arc, $\mathrm{FP}=$ Frontal Pennine fault, $\mathrm{IH}=$ Internal Houiller fault, $\mathrm{Lu}=$ Luberon fault, $\mathrm{MD}=$ Middle Durance fault, $\mathrm{Ni}=$ Nimes fault, $\mathrm{SF}=$ Simplon fault, $\mathrm{SZ}=$ Sesia zone, $\mathrm{Tr}=$ Trevaresse fault, $\mathrm{Ve}=$ Ventoux fault. Other abbreviations and symbols as in Figure 1; (b) Cross section through the northwestern Alps. The black shaded lines over the section tentatively indicate the shape of the uplifted Helvetic and Penninic nappes before their removal by erosion (modified after [150]). IL $=$ Insubric line. The inset in A shows the distribution, along the outer border of the GSB arc, of historical earthquakes with $\mathrm{M} \geq 5$ or $\mathrm{I} \geq \mathrm{VII}$ [151]. 
near the Nimes fault [153] suggests that in southern France strong earthquakes $(M>6)$ may have long return times.

In the Western Alps, the shortening induced by the Iberian push has been accommodated by a variety of tectonic processes, including uplift, dextral transpression, lateral escape and relative rotation of wedges and oroclinal bending of belt segments. Since the deformation pattern during the above process has been controlled by the minimum action principle, the location and geometry of extrusion processes have been mainly influenced by the direction of maximum stress and, above all, by the location and dimensions of the lithospheric domains that have opposed the least resistance to be overthrust by the escaping buoyant orogenic material.

In the Southwestern Alps, the above interpretation is compatible with the fact that the extruding wedges have moved towards the thinned zone lying in the Liguro-Provencal basin (Figure 12) and the driving compression (due to the Iberia-Eurasia convergence) is oriented almost perpendicular to the escaping wedges of the Liguran Alps. This extrusion process has been allowed by the activation of a number of lateral transpressional guides locally associated with pull-apart mechanisms (Figure 12 [154]). The roughly $\mathrm{E}-\mathrm{W}$ oriented compressional fronts where the above wedges overthrust the thinned Ligurian crust have been recognized by seismic surveys [55]-[155] and by the location of major shocks (Figure 2).

The hypothesis that the above extrusion mechanism is driven by the push of the Iberia plate is compatible with the significant correlation that can be recognized between the time patterns of seismic activity in Portugal and Southwestern Alps (Figure 13).

The fault system located in the Portugal zone is interpreted by [1] as a decoupling zone between the Iberian block and the Atlantic-Eurasia plate. This hypothesis implies that each strong earthquake at that fault system may trigger an acceleration of the Iberia plate, that then develops at rates compatible with the rheological properties of such structures. When the effects of such plate acceleration, transmitted by the French foreland, reach the Southwestern Alps, stress may undergo a significant increase at the boundaries of the Ligurian extruding wedge (Figure 12). This tentative interpretation might explain why the periods of highest seismic activity at the boundaries of the Ligurian wedge have mainly occurred in close time correspondence with the periods of highest activity in the Portugal fault system (Figure 13).

In the Northwestern Alps, the Cenozoic orogenic processes have produced a complex nappe system, resulting from the deformation of the European and Adriatic continental margins and the interposed oceanic sectors and microcontinents [156]. In between the Adriatic domain and the European foreland several paired deformed belts, each comprising nappes derived from the pre-Mesozoic crustal basement and from the related sedimentary covers, can be recognized (e.g., the Southalpine, Austroalpine, Pennine and Helvetic nappes). Moreover, the Alpine edifice is flanked by two major foreland basins, the Padanian basin to the south and the Molasse basin to the north. Generally, the Alpine orogeny is attributed to the effect of the roughly N-S Adriatic- 

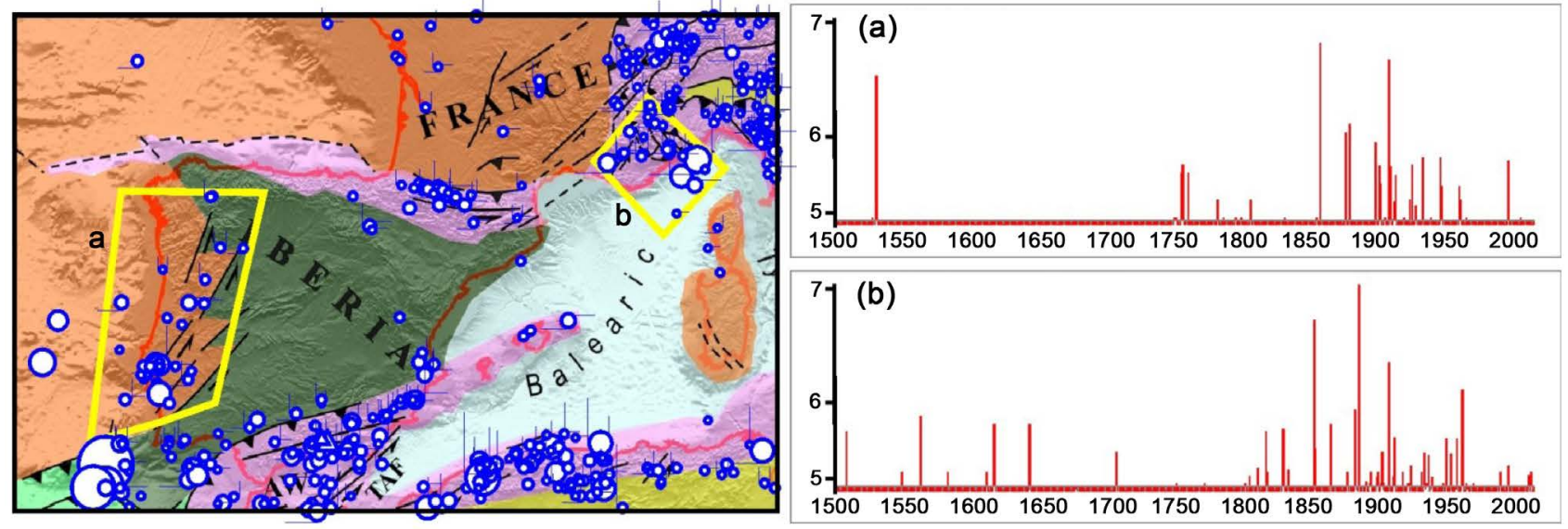

Figure 13. Time patterns of seismicity in the Portugal and Southwestern Alps-Ligurian basin since 1500 A.D. The configurations of the zones considered are depicted by green lines in the map. See text for comments. (a) West lberian fault system; (b) Southwestern alps and ligurian basin.

Eurasia convergence, which would have induced first the subduction and closure of the interposed oceanic domains (Piedmont and Valais), then the collision of the continental margins [157]. However, some pieces of evidence suggest that the above-mentioned Iberia-Eurasia convergence could have played a significant role in the development of the Western Alps:

1) The earlier orogenic phases in the Western Alps (Paleocene-Eocene) are compatible with a N-S to NNW-SSE convergence between Adriatic and Eurasia [158]. However, a different structural pattern has developed since the Oligocene, with thrust activity controlled by roughly ESEW-NW convergence (e.g., the Digne nappe in Provence [158]). This phenomenon could be an effect of the Iberia-Eurasia convergence.

2) It is suggested that several N-S or NE-SW trending tectonic lineaments in the western Alpine arc have behaved as dextral transpressional faults since the Miocene [159]. The kinematics of such structures, often corresponding to the boundaries of the main nappe systems (e.g., the Chamonix Line, Frontal Pennine Fault, Brianconnais Front and Internal Houiller Fault in [159] (Figure 12), are compatible with a regional stress field generated by the combination of the NW-SE Adriatic-Eurasia and NE-SW Iberia-Eurasia convergence. Moreover, the Insubric Fault Zone (Figure 12), i.e. the western sector of the major Periadriatic Fault system separating the Austroalpine from Southalpine domains [160], shows a similar dextral transpressional kinematics [159].

3) Many works have addressed the long-term exhumation pattern of the External Cristalline Massifs (i.e., Argentera-Mercantour, Pelvoux, Belledonne, Aiguilles RougesMont Blanc and Aar-Gotthard), which currently outcrop along the outer sector of the western Alpine arc [159] [161]-[167] (Figure 12). Such methamorphic/magmatic massifs, wich represent tectonic nappes of the European upper crust, have undergone a rather uniform exhumation process since the Miocene or earlier, mostly involved in compressional or transpressional mechanisms. In particular, the role of NE-SW dextral strike-slip and transpressional faults in the exhumation of the Mont Blanc massif is suggested by [162] [167]. As discussed above, the dextral transpression recognized 
along the outer Alpine arc may be related to the effect of the Iberia-Eurasia convergence.

4) In the northern sector of the western Alpine arc (i.e. the Swiss Alps), a complex nappe stacking has formed since the Oligocene [156]. During that period, the European crust has been strongly shortened, forming the Helvetic nappes that have been then overthrusted by the Pennine nappes. In particular, the sedimentary cover of the Pennines has been detached from its basement and emplaced over the Helvetics until the early Miocene [168] [169] [170]. Since then, this nappe edifice has undergone considerable exhumation, erosion and lateral bending (Figure 12). For instance, a large body of the Penninic nappes was uplifted and completely eroded, causing the separation of the basement Penninic nappes from the remnants of the deformed sedimentary cover (Prealps Klippen [156] [170]; Figure 12). Moreover, in between these inner and outer Pennine units the underlying Helvetic nappe and their basement (Mont Blanc-Aiguilles Rouges and Aar-Gotthard) have outcropped. It is worth noting that the tectonic contact between the inner Pennine and Helvetic nappes (i.e. the Pennine Thrust Front) is markedly curved outward in the zone that separates the outcropping Mont Blanc and Aar massifs [156] [171] [172], hereafter indicated as Grand San Bernard arc (GSB) (Figure 1 and Figure 12). Furthermore, it may be pointed out that such zone has a very peculiar structural setting, because it corresponds to a broad crustal synform whose axis is roughly N-S directed (the Rawil depression [156]). The presence of such crustal fold within the GSB is still debated and quite puzzling in the context of current tectonic models of Swiss Alps [156], which suggests that the development of this part of the Alpine orogen was an effect of a roughly N-S compressional regime induced by the Adriatic-Europe convergence [157]. On the other hand, it seems plausible that the Rawil depression has been generated by a shortening process almost orthogonal to the above plate convergence. In this regard, we suggest that the shortening required by the roughly SW-NE convergence between Iberia and Eurasia has been accommodated in the Swiss Alps by uplift and outward horizontal bending of Helvetic and Penninic units around the GSB. Such bending has been mainly influenced by the location of the surrounding more rigid and exhuming External Cristalline Massifs, as the Mont Blanc and Aar. In this context, the Rawil depression might mark the zone where the GSB achieved its maximum curvature, i.e. where crustal folding occurred in order to accommodate the strong horizontal oroclinal bending.

5) Significant geomorphological processes and seismic activity are recognized around the GSB. Indeed, such sector of the Western Alps is affected by remarkable uplift, only in part attributable to post-glacial rebound [173] [174]. Furthermore, a number of historical strong earthquakes (reaching $M=6.2$ ) are recorded along the outer border of the GSM arc, i.e. in the Rhone valley and Canton Valais [175] [176] [177] [178] (Figure 2 and Figure 12).

On the basis of above considerations, we propose that the compressional stress induced by the Iberia-Eurasia convergence has had a remarkable influence in the longterm evolution of the Western Alps since the Oligocene. At present, such push controls 
the seismotectonics of the northernmost sector of that zone, i.e. the Swiss Alps around the Grand Saint Bernard oroclinal arc.

\section{Geodetic Observations}

The space geodetic (GPS) observations obtained from about 760 continuous stations operating in the Italian region and surroundings from January 1, 2001 to December 31, 2015 have been analysed to estimate the present horizontal and vertical kinematic fields. The phase and pseudo-code data for each station have been analyzed by the GAMIT software version 10.5 [179] adopting a distributed procedure [180] as described by [45] [181]. The whole network has been divided into 43 clusters, following a simple geographic criterion, while maintaining the shortest possible baseline. Loose constraints $(100 \mathrm{~m})$ have been assigned to the daily position coordinates of each station belonging to all clusters. The International GPS service for Geodynamics (IGS) precise orbital solutions from Scripps Orbit and Permanent Array Center have been included in the processing with tight constraints, such as the Earth Orientation Parameter. The daily loosely constrained solutions have been combined into a unique solution by the GLOBK software [182], and aligned into the ITRF2008 reference frame [183] by a weighted six parameters transformation (three translations and three rotations), using the ITRF2008 coordinates and velocities of the 13 high-quality common IGS stations shown in the inset of Figure 14.

Then, the time series have been analyzed to estimate the north, east and vertical components of the geographical position of each site, following the procedure described by [45] [181]. Only the sites with a minimum observation length of 2.5 years have been included in the processing, in order to avoid biases generated by unreliable estimated seasonal signals [184] and/or by rate uncertainties, due to short time series [185]. Different methods have been developed to characterize noise in GPS time series and its impact on velocity uncertainties [186]-[191]. We have used the reformulated computation method of the Maximum Likelihood Estimation introduced by [189] in order to estimate the characteristics of the noise and the realistic uncertainties associated with velocity values. The resulting ITRF2008 horizontal velocity vectors with respect to the adopted Eurasian frame [183] are shown in Figure 14.

The kinematic pattern shown in that figure indicates that the outer sector of the Apennine belt moves considerably faster and with a greater eastward component with respect to the inner belt. This evidence is compatible with the kinematics of the belt that can be inferred from the distribution of Quaternary deformation [40], described earlier.

On the other hand, the above kinematics can hardly be reconciled with the implications of the geodynamic hypothesis that invoke the gravitational sinking of the Adriatic subducted lithosphere beneath the Apennine belt as the main driving mechanism of surface tectonics. Above all, it must be considered that the development of the presumed slab roll-back and consequent trench retreat along the Apennine belt is described with considerable uncertainty in literature. In particular, most authors [25] [192] [193] suggest that the evidence of subducted lithosphere beneath the Apennine 


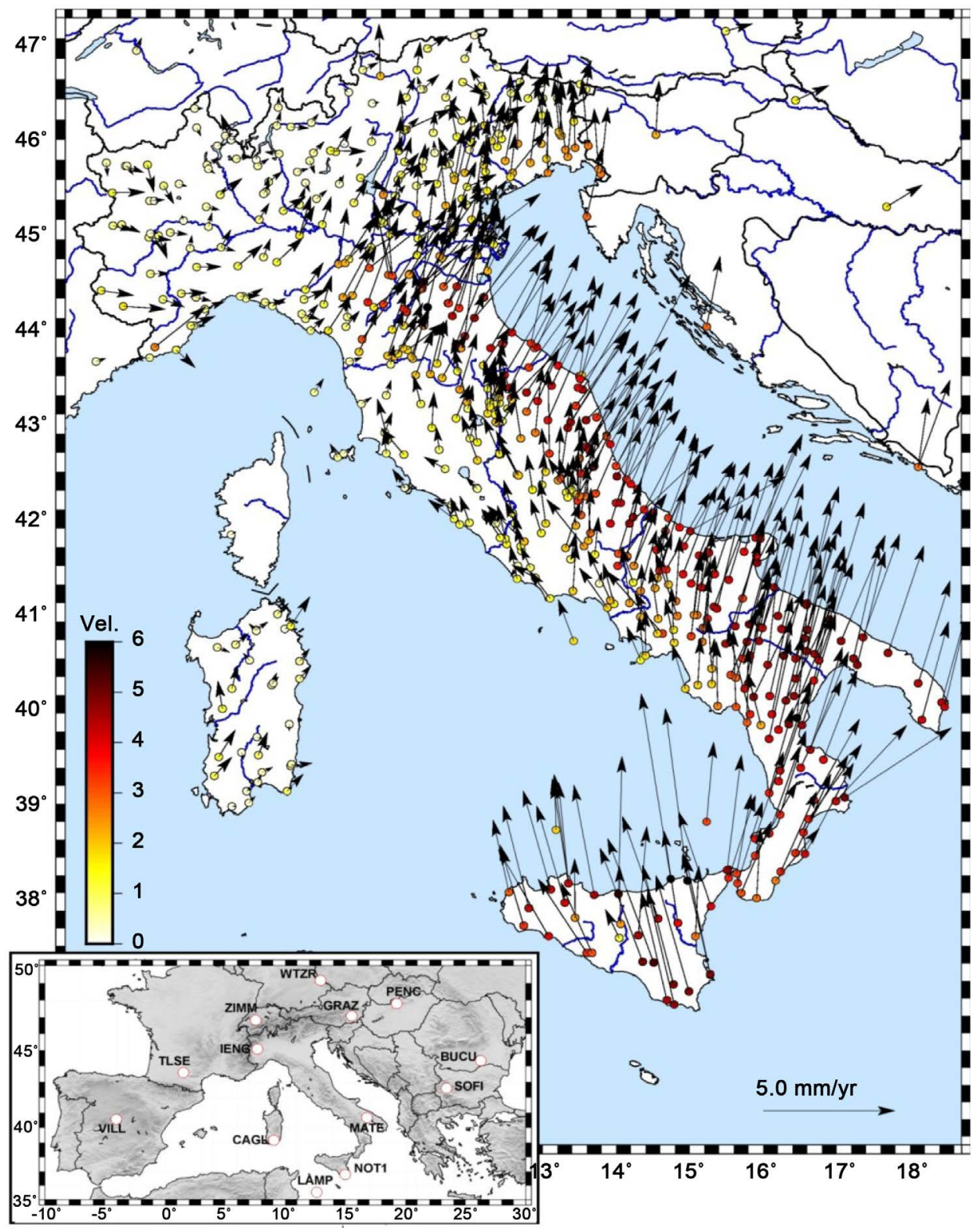

Figure 14. Horizontal velocities (blue vectors) of the GPS sites with respect to a fixed Eurasian frame (Euler pole at $54.23^{\circ} \mathrm{N}, 98.83^{\circ} \mathrm{W}, \omega=0.257^{\circ} / \mathrm{Myr}$ [183]). The inset shows the location of the 13 IGS stations that have been used to align the daily solutions of the network to the ITRF 2008 references frame [183].

belt is lacking in large sectors of the trench zone. Thus, it is difficult to assume such a discontinuous process as the driving mechanism of the present velocity field in the Apennines, which is characterized by a fairly uniform distribution of rates and orientations all along the belt (Figure 14). Furthermore, the above interpretation can hardly explain why the inner Apennine belt has such a different kinematics with respect to the outer belt, as also noted by [194]. This last difficulty is also pointed out by the results of numerical modelling, which show that the NE-ward roll-back of the Adriatic plate is 
expected to induce a similar motion in the upper plate [195], that in this case corresponds to the inner (Tyrrhenian) side of the Apennines.

The very low motion rates observed in the Western Padanian zone (Figure 14) are compatible with the fact that such area lies at the collision zone between two convergent indenters, the Adria plate on one side and the Iberia plate on the other side, and the fact that such convergence may hardly be accommodated by further shortening, since that process is strongly resisted by the presence of huge volumes of highly buoyant crustal material [8] [196] [197]. The fact that the GPS velocity vectors in the Western Alps and Western Padania are characterized by a dominant eastward orientation might be influenced by the kinematics of the Iberia plate.

The vertical kinematic pattern derived by GPS data in the northern Italian region is shown in Figure 15.

It can be noted that the eastern part of the Po Valley (Emilia plain) is characterized by significantly higher subsidence rates (up to $9 \mathrm{~mm} /$ year), with respect to the western part of that area, i.e. the Lombardia-Piemonte plain (from 1 to $-1 \mathrm{~mm} /$ year). Since anthropic activities in these two Padanian sectors are comparable (see for instance, the discussion given by [45]), it seems plausible that the cause of the different vertical kinematics in such zones (Figure 15) is most probably related to tectonic movements. In this regard, one could consider that the proposed underthrusting process at the Giudicarie discontinuity (Figure 5) is expected to cause subsidence in the underthrusting eastern Adriatic domain and uplift in the western Adriatic domain. The almost null vertical velocities observed in the western Po Valley (Figure 15) could result from the combination of anhtropic subsidence and tectonic uplift. The above interpretation is consistent with the fact that the boundary between the subsiding and the not subsiding Padanian sectors nearly corresponds to the presumed SW ward prolongation of the Giudicarie lineament [67] [69] [198].

The short term pattern of vertical velocities given in Figure 15 is compatible with the results of repeated levelling campaigns that have been performed since 1950 by Istituto Geografico Militare Italiano [199], and thereafter by other local regional authorities, companies and institutions [200] [201] [202]. In particular, the results of IGMI leveling campaigns carried out in the period 1897-1957 [203] point out a dominant subsidence in the eastern Po Valley, with rates increasing from west $(1-2 \mathrm{~mm} / \mathrm{yr}$ ) to east (5 - 7 $\mathrm{mm} / \mathrm{yr}$ ), and prevalent uplift in the western part of the valley (Lombard plain), with velocities mostly lower than $2 \mathrm{~mm} / \mathrm{yr}$, except a narrow E-W belt in the Monferrato zone, where uplift rates reach $3.5 \mathrm{~mm} / \mathrm{yr}$. These results indicate that the LombardiaPiemonte region underwent uplift in a period when anthropic activity was much less developed with respect to the recent/present time.

\section{Conclusions}

It is argued that seismotectonic activity in the Padanian zone and surrounding belts is conditioned by the kinematics of the Adria and Iberia plates, induced by the roughly NNE ward motion of Africa and the westward motion of the Anatolian-Aegean-Balkan system with respect to Eurasia (Figure 11). 


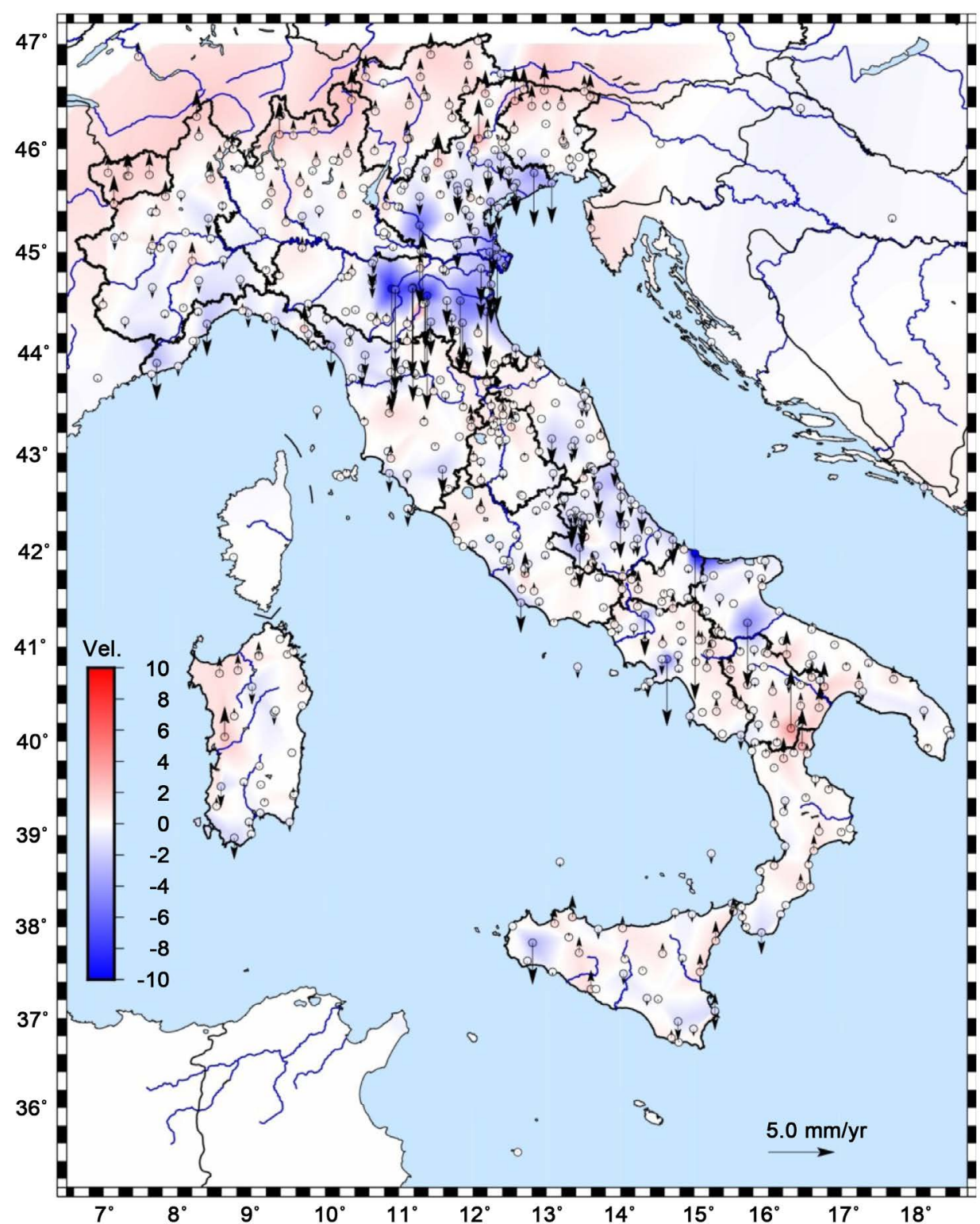

Figure 15. Vertical velocities (mm/yr) obtained by the analysis of GPS data in the ITRF2008 reference frame. The red and blue colours indicate uplift and subsidence respectively, with tones compatible with the chromatic scale given in the figure.

This geodynamic context can plausibly explain why the major seismic sources $(M>$ 5.5) of the region lying west of the Schio-Vicenza fault system are located in the Giudicarie zone, the outer front of the Northern Apennines, the offshore of the Ligurian coast and the Swiss Alps.

The occurrence of strong earthquakes in the central Padanian zone may be related with the underthrusting of the Adriatic lithosphere lying east of the Giudicarie discontinuity beneath the Adria domain which lies west of that thrust fault system. This process may have generated the strong earthquake $(M=6.7)$ that occurred in the Verona area in 1117 A.D. The roughly S-N compressional regime recognized in the external 
part of the Northern Apennines and the related seismic activity is explained as an effect of the kinematics and deformation pattern of the outer sector of the Apennine belt, that, stressed by Adria, has undergone uplift and outward escape.

The oblique convergence between the Adria and Iberia plates (Figure 11) has induced a compressional regime in the Western Padanian area and Western Alps, that may be responsible for the deformation and uplift of the northernmost edge of the Apennine belt (Monferrato arc). In the Southwestern Alps, the above constrictional context may have caused the lateral escape of a wedge towards the thinned crust located in the Ligurian basin. The lateral guides of this extrusion process correspond to strike-slip fault system, locally associated with pull-apart mechanisms, in the Italian-French Alps. This could explain the presence of extensional features in such area. The seismicity, even characterized by strong shocks (up to $M=7$ ), that has occurred offshore the Western Ligurian coast may be associated with the outer thrust front of the above extruding wedge. The hypothesis that seismotectonic activity in the Southwestern Alps is conditioned by the push of the Iberia plate is supported by the fact that the strongest shocks in such zone have occurred during the periods of highest seismic activity in the Portugal fault system (Figure 13), that represents the main decoupling zone between the Iberia plate and the Atlantic-Eurasia domain.

In the Northwestern Alps, the proposed compressional regime has been accommodated by the reorganization of buoyant masses, in particular by the uplift, lateral escape and bending of Pennine units. This process is supposed to be responsible for the seismic activity that occurs along the outer border of the main Pennine arc in the Grand Saint Bernard arc.

It must be pointed out that the proposed geodynamic interpretation is not compatible with the roughly SE-NW Africa-Eurasia convergence trend proposed by global kinematic models [204] [205] [206], since it would not induce the constrictional regime in the southern France, Western Alps and western Padanian zone that can account for the observed shortening patterns. In particular, the above plate convergence cannot account for the sinistral transpressional regime observed in the Pyrenean belt. The roughly NW ward push of Africa, transmitted by the Alboran wedge, would rather imply a clockwise rotation of Iberia, which would produce an extensional regime in the Pyrenean belt. This remark integrates the discussions reported in previous works [1] [38] [39] [51], which point out other major difficulties that one must face for reconciling the implications of the global kinematic models with primary evidence in the whole Mediterranean region. The above works also argue that any difficulty can be overcome if the Africa-Eurasia kinematic pattern proposed by [1] is adopted.

\section{Acknowledgements}

We are grateful to an anonymous reviewer for his/her precious suggestions.

\section{References}

[1] Mantovani, E., Viti, M., Babbucci, D. and Albarello, D. (2007) Nubia-Eurasia Kinematics: 
An Alternative Interpretation from Mediterranean and North Atlantic Evidence. Annals of Geophysics, 50, 311-336.

[2] Slejko, D., Carulli, G.B., Nicolich, R., Rebez, A., Zanferrari, A., Cavallin, A., Doglioni, C., Carraro, F., Castaldini, D., Iliceto, V., Semenza, E. and Zanolla, C. (1989) Seismotectonics of the Eastern Southern-Alps: A Review. Bollettino di Geofisica Teorica ed Applicata, 31, 109-136.

[3] Bressan, G., Bragato, P.L. and Venturini, C. (2003) Stress And Strain Tensors Based On Focal Mechanisms in the Seismotectonic Framework of the Friuli-Venezia Giulia Region (Northeastern Italy). Bulletin of the Seismological Society of America, 93, 1280-1297. https://doi.org/10.1785/0120020058

[4] Galadini, F., Poli, M.E. and Zanferrari, A. (2005) Seismogenic Sources Potentially Responsible For Earthquakes With $M \geq 6$ in the Eastern Southern Alps (Thiene-Udine Sector, NE Italy) Geophysical Journal International, 161, 739-762. https://doi.org/10.1111/j.1365-246X.2005.02571.x

[5] Viganò, A., Scafidi, D., Ranalli, G., Martin, S., Della Vedova. B. and Spallarossa, D. (2015) Earthquake Relocations, Crustal Rheology, and Active Deformation in the Central-Eastern Alps (N. Italy) Tectonophysics, 661, 81-98. https://doi.org/10.1016/j.tecto.2015.08.017

[6] Dondi, L., Mostardini, F. and Rizzini, A. (1982) Evoluzione Sedimentaria E Paleogeografia Nella Pianura Padana. In: Cremonini, G. and Ricci Lucchi, F., Eds., Guida Alla Geologia Del Margine Appenninico-Padano, Guida Geologiche Regionali della Società Geologica Italiana, Bologna, 47-58.

[7] Pieri, M. and Groppi, G. (1981) Subsurface Geological Structure of the Po Plain. Consiglio Naxionale delle Ricerche-Progetto Finalizzato Geodinamica, 414, 1-23.

[8] Fantoni, R. and Franciosi, R. (2010) Tectono-Sedimentary Setting of the Po Plain and Adriatic Foreland. Rendiconti dell Accademia dei Lincei, 21, S197-S209.

https://doi.org/10.1007/s12210-010-0102-4

[9] Ghielmi, M., Minervini, M., Nini, C., Rogledi, S., Rossi, M. and Vignolo, A. (2010) Sedimentary and Tectonic Evolution in the Eastern Po-Plain and Northern Adriatic Sea Area from Messinian to Middle Pleistocene (Italy). Rendiconti dell'Accademia dei Lincei, 21, S131-S166. https://doi.org/10.1007/s12210-010-0101-5

[10] Pola, M., Ricciato, A., Fantoni, R., Fabbri, P. and Zampieri, D. (2014) Architecture of the Western Margin of the North Adriatic Foreland: The Schio-Vicenza Fault System. Italian Journal of Geosciences, 133, 223-234. https://doi.org/10.3301/IJG.2014.04

[11] Turrini, C., Lacombe, O. and Roure, F. (2014) Present-Day 3D Structural Model of the Po Valley Basin, Northern Italy. Marine Petroleum Geology, 56, 266-289. https://doi.org/10.1016/j.marpetgeo.2014.02.006

[12] Turrini, C., Angeloni, P., Lacombe, O., Ponton, M. and Roure, F. (2015) Three-Dimensional Seismo-Tectonics in the Po Valley Basin, Northern Italy. Tectonophysics, 661, 156-179. https://doi.org/10.1016/j.tecto.2015.08.033

[13] Michetti, A.M., Giardina, F., Livio, F., Mueller, K., Serva, L., Sileo, G., Vittori, E., Devoti, R., Riguzzi, F., Carcano, C., Rogledi, S., Bonadeo, L., Brunamonte, F. and Fioraso, G. (2012) Active Compressional Tectonics, Quaternary Capable Faults, and the Seismic Landscape of the Po Plain (Northern Italy). Annals of Geophysics, 55, 969-1001.

[14] Vannoli, P., Burrato, P. and Valensise, G. (2014) The Seismotectonics of the Po Plain (Northern Italy): Tectonic Diversity in a Blind Faulting Domain. Pure Applied Geophysisics., 172, 1105-1142. https://doi.org/10.1007/s00024-014-0873-0

[15] Bigi, G., Cosentino, D., Parotto, M., Sartori, R. and Scandone, P. (1990) Structural Model 
Of Italy, 1:500,000. Consiglio Nazionale delle Ricerche, Progetto Finalizzato Geodinamica.

[16] Rovida, A., Camassi, R., Gasperini, P. and Stucchi, M. (Eds.) (2011) CPTI11, the 2011 Version of the Parametric Catalogue of Italian Earthquakes. Milano, Bologna.

http://emidius.mi.ingv.it/CPTI

[17] Faccenna, C., Piromallo, C., Crespo-Blanc, A., Jolivet, L. and Rossetti, F. (2004) Lateral Slab Deformation and the Origin of the Western Mediterranean Arcs. Tectonics, 23, TC1012. https://doi.org/10.1029/2002TC001488

[18] Rosenbaum, G. and Lister, G.S. (2004) Neogene and Quaternary Rollback Evolution of the Tyrrhenian Sea, the Apennines, and the Sicilian Maghrebides. Tectonics, 23, TC1013. https://doi.org/10.1029/2003TC001518

[19] Scrocca, D., Carminati, E., Doglioni, C. and Marcantoni, D. (2007) Slab Retreat and Active Shortening along the Central-Northern Apennines. In: Lacombe, O., Lavq, J., Roure, F. and Verges, J., Eds., Thrust Belts and Foreland Basins. From Fold Kinematics to Hydrocarbon Systems, Frontier in Earth Sciences, Springer, Berlin, 471-487.

https://doi.org/10.1007/978-3-540-69426-7 25

[20] Devoti, R., Esposito, A., Pietrantonio, G., Pisani, A.R. and Riguzzi, F. (2011) Evidence of Large Scale Deformation Patterns from GPS Data in the Italian Subduction Boundary. Earth Planetary Science Letters, 311, 230-241. https://doi.org/10.1016/j.epsl.2011.09.034

[21] Bennett, R.A., Serpelloni, E., Hreinsdóttir, S., Brandon, M.T., Buble, G., Basic, T., Casale, G., Cavaliere, A., Anzidei, M., Marjonovic, M., Minelli, G., Molli, G. and Montanari, A. (2012) Syn-Convergent Extension Observed Using the RETREAT GPS Network, Northern Apennines, Italy. Journal of Geophysical Research, 117, B04408.

https://doi.org/10.1029/2011JB008744

[22] Hassani, R., Jongmans, D. and Chery, J. (1997) Study of Plate Deformation and Stress in Subduction Processes Using Two Dimensional Numerical Models. Journal of Geophysical Research, 102, 17951-17965. https://doi.org/10.1029/97JB01354

[23] Schellart, W.P. (2005) Influence Of The Subducting Plate Velocity on the Geometry of the Slab and Migration of the Subduction Hinge. Earth Planetary Science Letters, 231, 197-219. https://doi.org/10.1016/j.epsl.2004.12.019

[24] Finetti, I.R., Boccaletti, M., Bonini, M., Del Ben, A., Pipan, M., Prizzon, A. and Sani, F. (2005) Lithospheric Tectono-Stratigraphic Setting of the Ligurian Sea-Northern ApenninesAdriatic Foreland from Integrated CROP Seismic Data. In: Finetti, I.R., Ed., Deep Seismic Exploration of the Central Mediterranean and Italy, CROP PROJECT, Elsevier, Amsterdam, Chapter 8, 119-158.

[25] Scafidi, D. and Solarino, S. (2012) Can Local Earthquake Tomography Settle The Matter About Subduction in the Northern And Central Apennines? Response from a New High Resolution P Velocity and Vp/Vs Ratio 3-D Model. Tectonophysics, 554-557, 63-73. https://doi.org/10.1016/j.tecto.2012.06.007

[26] Amato, A., Chiarabba, C. and Selvaggi, G. (1997) Crustal and Deep Seismicity in Italy (30 Years Later). Annali di Geofisica, 40, 981-993.

[27] Selvaggi, G. and Amato, A. (1992) Subcrustal Earthquakes in the Northern Apennines (Italy): Evidence for a Still Active Subduction? Geophysical Research Letters, 19/21, 21272130. https://doi.org/10.1029/92GL02503

[28] Solarino S., Ferretti G. and Eva, C. (2002) Seismicity of Garfagnana-Lunigiana (Tuscany, Italy) as Recorded by a Network of Semi-Broad-Band Instruments. Journal of Seismology, 6, 141-152. https://doi.org/10.1023/A:1015606132267

[29] De Luca, G., Cattaneo, M., Monachesi, G. and Amato, A. (2009) Seismicity in Central and 
Northern Apennines Integrating the Italian National and Regional Networks. Tectonophysics, 476, 121-135. https://doi.org/10.1016/j.tecto.2008.11.032

[30] Selvaggi, G. and Chiarabba, C. (1995) Seismicity and P-Wave Velocity Image of the Southern Tyrrhenian Subduction Zone. Geophysical Journal International, 121, 818-826.

https://doi.org/10.1111/j.1365-246X.1995.tb06441.x

[31] Magni, V., Van Hunen, J., Funiciello, F. and Faccenna, C. (2012) Numerical Models of Slab Migration in Continental Collision Zones. Solid Earth, 3, 293-306. https://doi.org/10.5194/se-3-293-2012

[32] Castellarin, A. and Vai, G.B. (1986) Southalpine versus Po Plain Apenninic Arcs. In: Wezel, F.C., Ed., The Origin of Arcs, Elsevier, Amsterdam, 253-280. https://doi.org/10.1016/b978-0-444-42688-8.50016-3

[33] Boccaletti, M. and Martelli, L. (a cura di) (2004) Carta Sismo-Tettonica Della Regione Emilia-Romagna, Scala 1:250,000 E Note Illustrative. Selca, Firenze.

[34] Boccaletti, M., Corti, G. and Martelli, L. (2010) Recent and Active Tectonics of the External Zone of the Northern Apennines (Italy). International Journal of Earth Sciences (Geologische Rundschau), 100, 1331-1348. https://doi.org/10.1007/s00531-010-0545-y

[35] Costa, M. (2003) The Buried, Apenninic Arcs of the Po Plain and Northern Adriatic Sea (Italy): A New Model. Bollettino della Società Geologica Italiana, 122, 3-23.

[36] Elter, F.M., Elter, P., Eva, C., Eva, E., Kraus, R.K., Padovano, M. and Solarino, S. (2012) An Alternative Model for the Recent Evolution of Northern-Central Apennines (Italy). Journal of Geodynamics, 54, 55-63. https://doi.org/10.1016/j.jog.2011.11.001

[37] Johnston, S.T., Weil, A.B. and Gutiérrez-Alonso, G. (2013) Oroclines: Thick and Thin. Geological Society of America Bulletin, 125, 643-663. https://doi.org/10.1130/B30765.1

[38] Mantovani, E., Viti, M., Babbucci, D., Tamburelli, C., Cenni, N., Baglione, M. and D'Intinosante, V. (2014) Generation of Back-Arc Basins as Side Effect of Shortening Processes: Examples from the Central Mediterranean. International Journals of Geosciences, 5, 1062-1079. https://doi.org/10.4236/ijg.2014.510091

[39] Mantovani, E., Viti, M., Cenni, N., Babbucci, D. and Tamburelli, C. (2015) Present Velocity Field in the Italian Region by GPS Data: Geodynamic/Tectonic Implications. International Journals of Geosciences, 6, 1285-1316. https://doi.org/10.4236/ijg.2015.612103

[40] Viti, M., Mantovani, E., Babbucci, D., Tamburelli, C., Cenni, N., Baglione, M. and D'Intinosante, V. (2015) Belt-Parallel Shortening in the Northern Apennines and Seismotectonic Implications. International Journal of Geosciences, 6, 938-961. https://doi.org/10.4236/iig.2015.68075

[41] Schellart, W.P., Freeman, J., Stegman, D.R., Moresi, L. and May, D. (2007) Evolution and Diversity of Subduction Zones Controlled by Slab Width. Nature, 446, 308-211. https://doi.org/10.1038/nature05615

[42] Boutelier, D., Oncken, O. and Cruden, A.R. (2013) Trench-Parallel Shortening in the Forearc Caused by Subduction along a Seaward-Concave Plate Boundary: Insights from Analogue Modelling Experiments. Tectonophysics, 611, 192-203. https://doi.org/10.1016/j.tecto.2013.11.028

[43] Mantovani, E., Babbucci, D., Tamburelli, C. and Viti, M. (2009) A Review ON THE Driving Mechanism of the Tyrrhenian-Apennines System: Implications for the Present Seismotectonic Setting in the Central-Northern Apennines. Tectonophysics, 476, 22-40. https://doi.org/10.1016/j.tecto.2008.10.032

[44] Mantovani, E., Viti, M., Babbucci, D., Ferrini, M., D’Intinosante, V. and Cenni, N. (2009) Quaternary Geodynamics of the Apennine Belt. Il Quaternario, 22, 97-108. 
[45] Cenni, N., Viti, M., Baldi, P., Mantovani, E., Bacchetti, M. and Vanucchi, A. (2013) Present Vertical Movements in Central and Northern Italy from GPS Data: Possible Role of Natural and Anthropogenic Causes. Journal of Geodynamics, 71, 74-85.

https://doi.org/10.1016/j.jog.2013.07.004

[46] Rosenbaum, G. and Lister, G.S. (2005) The Western Alps from the Jurassic to Oligocene: Spatiotemporal Constraints and Evolutionary Reconstructions. Earth Science Reviews, 69, 281-306. https://doi.org/10.1016/j.earscirev.2004.10.001

[47] Babist, J., Handy, M.R., Konrad-Schmolke, M. and Hammerschmidt, K. (2006) Precollisional, Multistage Exhumation of Subducted Continental Crust: The Sesia Zone, Western Alps. Tectonics, 25, 1-25. https://doi.org/10.1029/2005TC001927

[48] Malusà, M.G., Faccenna, C., Garzanti, E. and Polino, R. (2011) Divergence in Subduction Zones and Exhumation of High Pressure Rocks (Eocene Western Alps). Earth Planetary Science Letters, 310, 21-32. https://doi.org/10.1016/j.epsl.2011.08.002

[49] Mantovani, E., Viti, M., Babbucci, D., Tamburelli, C. and Albarello, D. (2006) Geodynamic Connection between the Indentation of Arabia and the Neogene Tectonics of the CentralEastern Mediterranean Region. In: Dilek, Y. and Pavlides, S., Eds., Post-Collisional Tectonics and Magmatism in the Mediterranean Region and Asia, Geological Society of America, Special Paper, 409, 15-41. https://doi.org/10.1130/2006.2409(02)

[50] Viti, M., Mantovani, E., Babbucci, D. and Tamburelli, C. (2006) Quaternary Geodynamics and Deformation Pattern in the Southern Apennines: Implications for Seismic Activity. Bollettino della Società Geologica Italiana, 125, 273-291.

[51] Viti, M., Mantovani, E., Babbucci, D. and Tamburelli, C. (2011) Plate Kinematics and Geodynamics in the Central Mediterranean. Journal of Geodynamics, 51, 190-204.

https://doi.org/10.1016/j.jog.2010.02.006

[52] Giglia, G., Capponi, G., Crispini, L. and Piazza, M. (1996) Dynamics and Seismotectonics of the West-Alpine Arc. Tectonophysics, 267, 143-175.

https://doi.org/10.1016/S0040-1951(96)00093-5

[53] Delacou, B., Sue, C., Champagnac, J.-D. and Burkhard, M. (2004) Present-Day Geodynamics in the Bend of the Western and Central Alps as Constrained by Earthquake Analysis. Geophysisical Journal International, 158, 753-774. https://doi.org/10.1111/j.1365-246X.2004.02320.x

[54] Kastrup, U., Zoback, M.L., Deichmann, N., Evans, K.F., Giardini, D. and Michael, A.J. (2004) Stress Field Variations in the Swiss Alps and the Northern Alpine Foreland Derived from Inversion of Fault Plane Solutions. Journal of Geophysical Research, 109, B01402. https://doi.org/10.1029/2003JB002550

[55] Larroque, C., Delouis, B., Godel, B. and Nocquet, J.-M. (2009) Active Deformation at the Southwestern Alps-Ligurian Basin Junction (France-Italy Boundary): Evidence for Recent Change from Compression to Extension in the Argentera Massif. Tectonophysics, 467, 2234. https://doi.org/10.1016/j.tecto.2008.12.013

[56] Perrone, G., Eva, E., Cadoppi, P., Solarino S. and Fioraso, G. (2011) Seismotectonics of a Low-Deformation Area: The Central Western Alps (Italy). Bollettino di Geofisica Teorica ed Applicata, 52, 261-281.

[57] Bauve, V., Plateaux, R., Rolland, Y., Sanchez, G., Bethoux, N., Delouis, B. and Darnault, R. (2014) Long-Lasting Transcurrent Tectonics in SW Alps Evidenced by Neogene to PresentDay Stress Fields. Tectonophysics, 621, 85-100. https://doi.org/10.1016/j.tecto.2014.02.006

[58] Mantovani, E., Viti, M., Babbucci, D. and Tamburelli, C. (2007) Major Evidence on the Driving Mechanism of the Tyrrhenian-Apennines Trench-Arc-Back Arc System from CROP Seismic Data. Bollettino della Società Geologica Italiana, 126, 459-471. 
[59] Mantovani, E., Viti, M., Babbucci, D., Cenni, N., Tamburelli, C., Vannucchi, A., Falciani, F., Fianchisti, G., Baglione, M., D’Intinosante, V. and Fabbroni, P. (2011) Sismotettonica Dell'Appennino Settentrionale. Implicazioni Per La Pericolosità Sismica Della Toscana. Regione Toscana, Centro stampa Giunta Regione Toscana, Firenze.

http://www.regione.toscana.it/documents/10180/11608181/sismotettonica $\mathrm{rt} / 72318222$-d6f 1-4374-a356-9fa611c4d280

[60] Mantovani, E., Viti, M., Babbucci, D., Cenni, N., Tamburelli, C., Vannucchi, A., Falciani, F., Fianchisti, G., Baglione, M., D'Intinosante, V. and Fabbroni, P. (2012) Potenzialità Sismica Della Toscana E Definizione Di Criteri Per Interventi Di Prevenzione. Regione Toscana, Centro stampa Giunta Regione Toscana, Firenze.

http://www.regione.toscana.it/documents/10180/11608181/volume2 potenzialitasismicadel latoscana/056d54ce-3412-4c31-9439-40653379760c

[61] Mantovani, E., Viti, M., Babbucci, D., Cenni, N., Tamburelli, C., Vannucchi, A., Falciani, F., Fianchisti, G., Baglione, M., D’Intinosante, V., Fabbroni, P., Martelli, L., Baldi, P. and Bacchetti, M. (2013) Assetto Tettonico E Potenzialità Sismica Dell'appennino ToscoEmiliano-Romagnolo E Val Padana. Regione Toscana e Regione Emilia-Romagna, Centro Stampa-Regione Emilia-Romagna.

http://ambiente.regione.emilia-romagna.it/geologia/servizio-geologico-sismico-suoli http://www.rete.toscana.it/sett/pta/ sismica/index.shtml

[62] Viti, M., Mantovani, E., Babbucci, D. and Tamburelli, C. (2009) Generation of Trench-ArcBack-Arc Systems in the Western Mediterranean Region Driven by Plate Convergence. Bollettino della Società Geologica Italiana, 128, 89-106.

[63] Molnar, P. and Lyon-Caen, H. (1988) Some Simple Physical Aspects of the Support, Structure and Evolution of Mountain Belts. Geological Society of America Special Paper, 218, 179-207. https://doi.org/10.1130/SPE218-p179

[64] Cloos, M. (1993) Lithospheric Buoyancy and Collisional Orogenesis: Subduction of Oceanic Plateaus, Continental Margins, Island Arcs, Spreading Ridges, and Seamounts. Geological Society of America Bulletin, 105, 715-737. https://doi.org/10.1130/0016-7606(1993)105<0715:LBACOS >2.3.CO;2

[65] Masek, J.G. and Duncan, C.C. (1998) Minimum-Work Mountain Building. Journal of Geophysical Research, 103, 907-917. https://doi.org/10.1029/97JB03213

[66] Mantovani, E., Albarello, D., Babbucci, D., Tamburelli, C. and Viti, M. (2000) Genetic Mechanism of Back-Arc Opening: Insights from the Mediterranean Deformation Pattern. In: Boschi, E., et al., Eds., Problems in Geophysics for the New Millennium, Bologna, Editrice Compositori, 151-178.

[67] Viola, G., Mancktelow, N.S. and Seward, D. (2001) Late Oligocene-Neogene Evolution of Europe-Adria Collision: New Structural and Geochronological Evidence from the Giudicarie Fault System (Italian Eastern Alps). Tectonics, 20, 999-1020. https://doi.org/10.1029/2001TC900021

[68] Castellarin, A. and TRANSALP Working Group (2004) Structural Synthesis of the Eastern Alps: A Collisional Orogenic Chain. Special Volume of the Italian Geological Society for the IGC 32 Florence-2004, 3-13.

[69] Castellarin, A., Vai, G.B. and Cantelli, L. (2006) The Alpine Evolution of the Southern Alps around the Giudicarie Faults: A Late Cretaceous to Early Eocene Transfer Zone. Tectonophysics, 414, 203-223. https://doi.org/10.1016/j.tecto.2005.10.019

[70] Frisch, W., Dunkl, I. and Kuhlemann, J. (2000) Post-Collisional Orogen-Parallel LargeScale Extension in the Eastern Alps. Tectonophysics, 327, 239-265.

https://doi.org/10.1016/S0040-1951(00)00204-3 
[71] Pomella, H., Stipp, M. and Fügenschuh, B. (2012) Thermochronological Record of Thrusting and Strike-Slip Faulting along the Giudicarie Fault System (Alps, Northern Italy). Tectonophysics, 579, 118-130. https://doi.org/10.1016/j.tecto.2012.04.015

[72] Semenza, E. (1974) La Fase Giudicariense, Nel Quadro Di Una Nuova Ipotesi Sull'orogenesi Alpina Nell'area Italo-Dinarica. Memorie della Società Geologica Italiana, 13, 187-226.

[73] Ratschbacher, L., Frisch, W., Linzer, H.G. and Merle, O. (1991) Lateral Extrusion in the Eastern Alps: Part 2. Structural Analysis. Tectonics, 10, 257-271. https://doi.org/10.1029/90TC02623

[74] Rosenberg, C.L., Brun, J.P., Cagnard, F. and Gapais, D. (2007) Oblique Indentation in the Eastern Alps: Insights from Laboratory Experiments. Tectonics, 26, TC2003. https://doi.org/10.1029/2006tc001960

[75] Wölfler, A., Kurz, W., Fritz, H. and Stüwe, K. (2011) Lateral Extrusion in the Eastern Alps Revisited: Refining the Model by Thermochronological, Sedimentary, and Seismic Data. Tectonics, 30, TC4006. https://doi.org/10.1029/2010tc002782

[76] Robertson, A. and Shallo, M. (2000) Mesozoic-Tertiary Tectonic Evolution of Albania in Its Regional Eastern Mediterranean Context. Tectonophysics, 316, 197-254. https://doi.org/10.1016/S0040-1951(99)00262-0

[77] Mercier, J., Sorel, D. and Simeakis, K. (1987) Changes in the State of Stress in the Overriding Plate of a Subduction Zone: The Aegean Arc from the Pliocene to the Present. Annales Tectonicae, 1, 20-39.

[78] Finetti, I.R. (2005) Ionian and Alpine Neotethyan Oceans Opening. In: Finetti, I.R., Ed., Deep Seismic Exploration of the Central Mediterranean and Italy, CROP PROJECT, Elsevier, Amsterdam, Chapter 6, 103-108.

[79] Del Ben A., Barnaba, C. and Taboga, A. (2008) Strike-Slip Systems as the Main Tectonic Features in the Plio-Quaternary Kinematics of the Calabrian Arc. Marine Geophysical Researches, 29, 1-12. https://doi.org/10.1007/s11001-007-9041-6

[80] Ben Avraham, Z., Boccaletti, M., Cello, G., Grasso, M., Lentini, F., Torelli, L. and Tortorici, L. (1990) Principali Domini Strutturali Originatisi Dalla Collisione Neogenico-Quaternaria Nel Mediterraneo Centrale. Memorie della Società Geolologica Italiana, 45, 453-462.

[81] Lentini, F., Carbone, S. and Guarnieri, P. (2006) Collisional and Postcollisional Tectonics of the Apenninic-Maghrebian Orogen (Southern Italy). In: Dilek, Y. and Pavlides, S., Eds., Postcollisional Tectonics and Magmatism in the Mediterranean Region and Asia, Geological Society of America Special Paper, 409, 57-81. https://doi.org/10.1130/2006.2409(04)

[82] Westaway, R. (1993) Quaternary Uplift of Southern Italy. Journal of Geophysical Research, 98, 741-772. https://doi.org/10.1029/93JB01566

[83] Van Dijk, J.P. and Scheepers, P.J.J. (1995) Neogene Rotations in the Calabrian Arc. Implications for a Pliocene-Recent Dynamic Scenario for the Central Mediterranean. Earth Science Reviews, 39, 207-246. https://doi.org/10.1016/0012-8252(95)00009-7

[84] Moretti, I. and Royden, L. (1988) Deflection, Gravity Anomalies and Tectonics of Doubly Subducted Continental Lithosphere: Adriatic and Ionian Seas. Tectonics, 7, 875-893. https://doi.org/10.1029/TC007i004p00875

[85] Argnani, A., Frugoni, F., Cosi, R., Ligi, M. and Favali, P. (2001) Tectonics and Seismicity of the Apulian Ridge South of Salento Peninsula (Southern Italy). Annali di Geofisica, 44, 527540.

[86] Bosellini, A. (2004) The Western Passive Margin of Adria and Its Carbonate Platforms. Special Volume of the Italian Geological Society for the IGC 32 Florence, 79-92. 
[87] Ciarapica, G. and Passeri, L. (2005) Late Triassic and Early Jurassic Sedimentary Evolution of the Northern Apennines: An Overview. Bollettino della Società Geologica Italiana, 124, 189-201.

[88] De Paola, N., Collettini, C., Faulkner, D.R. and Trippetta, F. (2008) Fault Zone Architecture and Deformation Processes within Evaporitic Rocks in the Upper Crust. Tectonics, 27, TC4017. https://doi.org/10.1029/2007tc002230

[89] Mirabella, F., Barchi, M., Lupattelli, A., Stucchi, E. and Ciaccio, M.G. (2008) Insights on the Seismogenic Layer Thickness from the Upper Crust Structure of the Umbria-Marche Apennines (Central Italy). Tectonics, 27, TC1010. https://doi.org/10.1029/2007tc002134

[90] Boncio, P. and Lavecchia, G. (2000) A Structural Model for Active Extension in Central Italy. Journal of Geodynamics, 29, 233-244. https://doi.org/10.1016/S0264-3707(99)00050-2

[91] Calamita, F., Esestime, P. and Viandante, M.G. (2005) Tectonic Setting of the CentralSouthern Apennines. Rendiconti della Società Geolologica Italiana-Nuova Serie, 1, 66-68.

[92] Esestime, P., D’Arcangelo, S., Paltrinieri, W. and Calamita, F. (2006) Strutture Traspressive Della Catena Apulo Sepolta (Appennino Meridionale, Settore Campano-Molisano). Rendiconti della Società Geologica Italiana Nuova Serie, 2, 135-137.

[93] Piccardi, L., Tondi, G. and Cello, G. (2006) Geo-Structural Evidence for Active Oblique Extension in South-Central Italy. In: Pinter, N., et al., Eds., The Adria microplate: GPS Geodesy, Tectonics and Hazard, Springer-Verlag, Berlin-Heidelberg, 95-108.

[94] Ascione, A., Caiazzo, C. and Cinque, A. (2007) Recent Faulting in Southern Apennines (Italy): Geomorphic Evidence, Spatial Distribution and Implications for Rates of Activity. Bollettino della Società Geolologica Italiana (Italian Journal of Geosciences), 126, 293-305.

[95] Boncio, P. and Bracone, V. (2009) Active Stress from Earthquake Focal Mechanisms along the Padan-Adriatic Side of the Northern Apennines (Italy), with Considerations on Stress Magnitudes and Pore Fluid Pressures. Tectonophysics, 476, 180-194. https://doi.org/10.1016/j.tecto.2008.09.018

[96] Peccerillo, A. (2005) Plio-Quaternary Volcanism in Italy. Petrology, Geochemistry, Geodynamics. Springer-Verlag, Berlin-Heidelberg.

[97] Acocella, V. and Funiciello, R. (2006) Transverse Systems along the Extensional Tyrrhenian Margin of Central Italy and Their Influence on Volcanism. Tectonics, 25, TC2003. https://doi.org/10.1029/2005tc001845

[98] Calamita, F., Coltorti, M., Pieruccini, P. and Pizzi, A. (1999) Evoluzione Strutturale E Morfogenesi Plio-Quaternaria Dell'appennino Umbro-Marchigiano Tra Il Preappennino Umbro E La Costa Adriatica. Bollettino della Società Geolologica Italiana, 118, 125-139.

[99] Ghisetti, F. and Vezzani, L. (1999) Depth and Modes of Pliocene-Pleistocene Crustal Extension of the Apennines (Italy). Terra Nova, 11, 67-72. https://doi.org/10.1046/j.1365-3121.1999.00227.x

[100] Cerrina Feroni, A., Martelli, L., Martinelli, P., Ottria, G. and Sarti, G. (2001) The Romagna Apennines, Italy: An Eroded Duplex. Geological Journal, 36, 39-54. https://doi.org/10.1002/gj.874

[101] Argnani, A., Barbacini, G., Bernini, M., Camurri, F., Ghielmi, M., Papani, G., Rizzini, F., Rogledi, S. and Torelli, L. (2003) Gravity Tectonics Driven by Quaternary Uplift in the Northern Apennines: Insights from the La Spezia-Reggio Emilia Geo-Transect. Quaternary Intenational, 101-102, 13-26. https://doi.org/10.1016/s1040-6182(02)00088-5

[102] Bartolini, C. (2003) When Did the Northern Apennine Become a Mountain Chain? Quaternary International, 101-102, 75-80. https://doi.org/10.1016/S1040-6182(02)00090-3

[103] Bartolini, C., D’Agostino, N. and Dramis, F. (2003) Topography, Exhumation, and Drain- 
age Network Evolution of the Apennines. Episodes, 26, 212-216.

[104] Pizzi, A. (2003) Plio-Quaternary Uplift Rates in the Outer Zone of the Central Apennines Fold-and-Thrust Belt, Italy. Quaternary International, 101-102, 229-237. https://doi.org/10.1016/S1040-6182(02)00105-2

[105] Schiattarella, M., Di Leo, P., Beneduce, P. and Giano, S.I. (2003) Quaternary Uplift vs Tectonic Loading: A Case Study from the Lucanian Apennine, Southern Italy. Quaternary International, 101-102, 239-251. https://doi.org/10.1016/S1040-6182(02)00126-X

[106] Ascione, A., Cinque, A., Miccadei, E. and Villani, F. (2008) The Plio-Quaternary Uplift of the Apennines Chain: New Data from the Analysis of Topography and River Valleys in Central Italy. Geomorphology, 102, 105-118, https://doi.org/10.1016/j.geomorph.2007.07.022

[107] Santangelo, N., Di Donato, V., Lebreton, V., Romano, P. and Ermolli, E.R. (2012) Palaeolandscapes of Southern Apennines During the Late Early and the Middle Pleistocene. Quaternary International, 267, 20-29. https://doi.org/10.1016/j.quaint.2011.02.036

[108] Rogledi, S. (2010) Assetto Strutturale Delle Unità Alpine Nella Pianura Tra Il Lago d'Iseo E Il Garda. Presentazione al Convegno "Rischio sismico nella Pianura Padana", Museo Civico di Scienze Naturali, Brescia, 24 Novembre 2010.

http://ingegneriasismica.org/it/structural-setting-of-the-central-po-plain/

[109] Compagnoni, B. and Galluzzo, F. (2004) Geological Map of Italy 1:250,000 Scale. Especially printed for the 32nd International Geological Congress. SELCA, Florence, Italy.

[110] Mantovani E., Viti, M., Babbucci, D., Albarello, D., Cenni, N. and Vannucchi, A. (2010) Long-Term Earthquake Triggering in the Southern and Northern Apennines. Journal of Seismology, 14, 53-65. https://doi.org/10.1007/s10950-008-9141-Z

[111] Mantovani, E., Viti, M., Babbucci, D., Cenni, N., Tamburelli, C. and Vannucchi, A. (2012) Middle Term Prediction of Earthquakes in Italy: Some Remarks on Empirical and Deterministic Approaches. Bollettino di Geofisisica Teorica ed Applicata, 53, 89-111.

[112] Vanossi, M., Cortesogno, L., Gaggero, L., Galbiati, B., Laureti, L. and Peloso G.F. (1994) Stratigrafia Pre-Oligocenica E Paleogeografia. Guide Geologiche Regionali Volume 2. BEMA Editrice, Milano, 17-33.

[113] Decarlis, A., Dallagiovanna, G., Lualdi, A., Maino, M. and Seno, S. (2013) Stratigraphic Evolution in the Ligurian Alps between Variscan Heritages and the Alpine Tethys Opening: A Review. Earth-Science Reviews, 125, 43-68. https://doi.org/10.1016/j.earscirev.2013.07.001

[114] Bernini, M. Bertoldi, R., Papani, G and Vescovi, P. (1994) Evoluzione in Regime Compressivo Del Bacino Villafranchiano Di Compiano (Parma). Atti Ticinensi di Scienze della Terra, 37, 155-171.

[115] Farabegoli, E., Benini, A., Martelli, L., Onorevoli, G. and Severi, P. (1991) Geologia Dell'appennino Romagnolo Da Campigna A Cesenatico. Memorie Descrittive della Carta Geologica D' Italia, 56, 165-184.

[116] Bortolotti, V. (a cura di) (1992) Appennino Tosco-Emiliano. Guide Geologiche Regionali Volume 4, BE-MA, Milano.

[117] Martelli, L., Camassi, R., Catanzariti, R., Fornaciari, E., Peruzza, L., Spadafora, E. and Rio, D. (2002) Note Illustrative Della Carta Geologica d'Italia Alla Scala 1:50,000 Foglio 265 Bagno Di Romagna. SELCA, Firenze.

[118] Castellarin, A., Eva, C., Giglia, G. and Vai, G.B. (1985) Analisi Strutturale Del Fronte Appenninico Padano. Giornale di Geologia, 47, 47-75. 
[119] Sorgi, C., Deffontaines, B., Hippolyte, J.C. and Cadet, J.P. (1998) An Integrated Analysis of Transverse Structures in the Northern Apennines, Italy. Geomorphology, 25, 193-206. https://doi.org/10.1016/S0169-555X(98)00041-5

[120] Mantelli, L. and Vercesi, P.L. (2000) Evoluzione Morfostrutturale Recente Del Pedeappennino Vogherese. Atti Ticinensi di Scienze della Terra, 41, 49-58.

[121] Benedetti, L., Tapponnier, P., Gaudemer, Y., Manighetti, I. and Van der Woerd J. (2003) Geomorphic Evidence for an Emergent Active Thrust along the Po Plain: The BroniStradella Fault. Journal of Geophysical Research, 108, 2238, ETG6, 1-14. https://doi.org/10.1029/2001jb001546

[122] Ambrosetti, P., Bosi, C., Carraro, F., Ciaranfi, N., Panizza, M., Papani, G., Vezzani, L. and Zanferrari, A. (1983) Neotectonic Map of Italy. Quaderni della Ricerca Scientifica CNR, CNR-PFG, 4.

[123] Meisina, C. and Piccio, A. (2003) River Dynamics and Slope Processes along a Sector of The Villalvernia-Varzi Line (Northern Italy). Quaternary International, 101-102, 179-190. https://doi.org/10.1016/S1040-6182(02)00100-3

[124] Panini, F., Fioroni, C. and Fregni, P. (2004) Geologia Dell'area Di Varzi (Appennino Vogherese): Note Preliminari. Atti Ticinensi di Scienze della Terra, 45, 43-59.

[125] Bernini, M. and Papani, G. (1987) Alcune Considerazioni Sulla Struttura Del Margine Appenninico Emiliano Fra Lo Stirone E l'Enza (E Sue Relazioni Con Il Sistema Del F. Taro). L'Ateneo Parmense-Acta Naturalia, 23, 219-240.

[126] Vescovi, P. (1988) La Linea Trasversale Passo Della Cisa-Val Parma-Bassa Val d’Enza: 1. Sistema Trascorrente Sinistro Nella Zona Del Passo Della Cisa (Prov. Di Parma). L'Ateneo Parmense-Acta Naturalia, 24, 221-243.

[127] Guidoboni, E., Comastri, A. and Boschi, E. (2005) The "Exceptional" Earthquake of 3 January 1117 in the Verona Area (Northern Italy): A Critical Time Review and Detection of Two Lost Earthquakes (Lower Germany And Tuscany). Journal of Geophysical Research, 110, B12309. https://doi.org/10.1029/2005JB003683

[128] Martinez-Diaz, J.J. and Hernandez-Enrile, J.L. (2004) Neotectonics and Morphotectonics of the Southern Almeria Region (Betic Cordillera-Spain): Kinematic Implications. International Journal of Earth Sciences (Geologische Rundschau), 93, 189-206. https://doi.org/10.1007/s00531-003-0379-y

[129] Martínez-Díaz, J.J., Masana, E. and Ortuño, M. (2012) Active Tectonics of the Alhama De Murcia Fault, Betic Cordillera, Spain. Journal of Iberian Geology, 38, 253-270. https://doi.org/10.5209/rev JIGE.2012.v38.n1.39218

[130] Cabral, J. (2012) Neotectonics of Mainland Portugal: State of the Art and Future Perspectives. Journal of Iberian Geology, 38, 71-84. https://doi.org/10.5209/rev JIGE.2012.v38.n1.39206

[131] Martín-González, F., Antón, L., Insua, J.M., De Vicente, G., Martínez-Díaz, J.J., MuñozMartín, A., Heredia, N. and Olaiz, A. (2012) Seismicity and Potencially Active Faults in the Northwest and Central-West Iberian Peninsula. Journal of Iberian Geology, 38, 52-69. https://doi.org/10.5209/rev JIGE.2012.v38.n1.39205

[132] Calvet, M. (1999) Régimes Des Contraintes Et Volumes De Relief Dans L'est Des Pyrénées/Stress Regimes and Volumes of Reliefs in the Eastern Pyrenees. Géomorphologie, 5, 253-278. https://doi.org/10.3406/morfo.1999.991

[133] Lacan, P. and Ortuno, M. (2012) Active Tectonics of Pyrenees: A Review. Journal of Iberian Geology, 38, 9-30. https://doi.org/10.5209/rev JIGE.2012.v38.n1.39203

[134] Larue, J.-P. (2004) Évolution Tectonique Et Morphodynamique De La Bordure Sud Du 
Massif Central, Entre La Cesse Et l'Hérault (France). Bulletin Societe Géologique de France, 175, 547-560. https://doi.org/10.2113/175.6.547

[135] Larue, J.-P. (2007) Incision Fluviatile Et Tectonique Dans La Montagne Noire (Sud Du Massif Central Français). Géographie physique et Quaternaire, 61, 145-163. https://doi.org/10.7202/038989ar

[136] Giusti, C. (2008) Asymetrie Topographique Et Morphogenetique Dans Le Sud Du Massif Central (France). Bulletin de I Association de Géographes Français, BAGF-Géographies, 2, 254-270. https://doi.org/10.3406/bagf.2008.2620

[137] Lacombe, O. and Mouthereau, F. (1999) Qu'est-Ce Que Le Front Des Orogènes? L'exemple De I'orogène Pirénéen/What Is the Real Front of Orogens? The Pyrenean Orogen as a Case Study. Comptes Rendus Academic des Sciences Paris, Sciences de la Terre et des Planetes, 329, 889-896.

[138] Rocher, M., Lacombe, O., Angelier, J., Deffontaines, B. and Verdier, F. (2000) Cenozoic Folding and Faulting in the South Aquitaine Basin (France): Insights from Combined Structural and Paleostress Analyses. Journal of Structural Geology, 22, 627-645. https://doi.org/10.1016/S0191-8141(99)00181-9

[139] Michon, L. and Merle, O. (2001) The Evolution of the Massif Central Rift: Spatio-Temporal Distribution of the Volcanism. Bulletin de la Societe Géologique de France, 172, 201-211. https://doi.org/10.2113/172.2.201

[140] Mazabraud, Y., Bethoux, N. and Deroussi, S. (2005) Characterisation of the Seismological Pattern in a Slowly Deforming Intraplate Region: Central and Western France. Tectonophysics, 409, 175-192. https://doi.org/10.1016/j.tecto.2005.08.021

[141] Nowell, D.A.G., Jones M.C. and Pyle, D.M. (2006) Episodic Quaternary Volcanism in France and Germany. Journal of Quaternary Science, 21, 645-675. https://doi.org/10.1002/jqs.1005

[142] Ziegler, P.A. and Dèzes P. (2007) Cenozoic Uplift of Variscan Massifs in the Alpine Foreland: Timing and Controlling Mechanisms. Global Planetary Change, 58, 237-269. https://doi.org/10.1016/j.gloplacha.2006.12.004

[143] Josnin, J.-Y., Arthaud, F. and Drogue, C. (1998) Mouvements Verticaux Quaternaires Dans Ie Languedoc Mediterraneen Oriental Et Leurs Consequences Sur I'hydrologeologie Karstique. Comptes Rendus Academic des sciences Paris, Sciences de la Terre et des Planetes, 326, 709-716.

[144] Lacassin, R., Meyer, B., Benedetti, L., Armijo, R. and Tapponnier, P. (1998) Signature Morphologique De I'activite De La Faille Des Cevennes (Languedoc, France). Comptes Rendus Academic des sciences Paris, Sciences de la Terre et des Planetes, 326, 807-815.

[145] Peulvast, J.-P., Baroux, E., Bellier, O. and Sébrier, M. (1999) Le Problème De L'activité Des Failles De Nîmes, De Salon-Cavaillon Et De La Moyenne Durance (SE De La France): Apports De La Géomorphologie Structurale. Géomorphologie, 5, 327-358. https://doi.org/10.3406/morfo.1999.998

[146] Champion, C., Choukroune, P. and Clauzon G. (2000) La Déformation Post-Miocène En Provence Occidentale. Geodinamica Acta, 13, 67-85. https://doi.org/10.1080/09853111.2000.11105365

[147] Dutour, A., Philip, H., Jaurand, E. and Combes, P. (2002) Mise En Evidence De Déformations En Faille Inverse Avec Ruptures De Surface Cosismiques Dans Les Dépôts Würmiens Du Versant Nord Du Mont Ventoux (Provence Occidentale, France). Comptes Rendus Géoscience, 334, 849-856. https://doi.org/10.1016/S1631-0713(02)01820-5

[148] Cushing, E.M., Bellier, O., Nechtschein, S., Sébrier, M., Volant, P., Lomax, A., Dervin, P., 
Guignard, P. and Bove, L. (2008) A Multidisciplinary Study of a Slow-Slipping Fault for Seismic Hazard Assessment: The Example of the Middle Durance Fault (SE France). Geophysical Journal International, 172, 1163-1178. https://doi.org/10.1111/j.1365-246X.2007.03683.x

[149] Amorèse, D., Lagarde, J.-L., Baroux, E., Font, M. and Santoire, J.-P. (2009) Accurate Analysis of the Distribution of Epicenters in Western Provence and Eastern Languedoc (Southern France). Journal of Geodynamics, 47, 20-29. https://doi.org/10.1016/j.jog.2008.06.003

[150] Angiboust, S., Glodny, J., Oncken, O. and Chopin, C. (2014) In Search of Transient Subduction Interfaces in the Dent Blanche-Sesia Tectonic System (W. Alps). Lithos, 205, 298-321. https://doi.org/10.1016/j.lithos.2014.07.001

[151] Mayer-Rosa, D. and Schwarz-Zanetti, G. (2004) On Historical Earthquakes in Switzerland: Summary of Compilations and Investigations. Annals of Geophysics, 47, 621-630.

[152] Chardon, D. and Bellier, O. (2003) Geological Boundary Conditions of the 1909 Lambesc (Provence, France) Earthquake: Structure and Evolution of the Trévaresse Ridge Anticline. Bulletin de la Societe géologique de France, 174, 497-510. https://doi.org/10.2113/174.5.497

[153] Volant, P., Levret, A., Carbon, D., Scotti, O., Combescure, D., Verdel, T., Piant, A. and Laurent, P. (2009) An Archaeo-Seismological Study of the Nimes Roman Aqueduct, France: Indirect Evidence for an $M>6$ Seismic Event? Natural Hazards, 49, 53-77. https://doi.org/10.1007/s11069-008-9276-9

[154] Sage, F., Beslier, M.-O., Thinon, I., Larroque, C., Dessa, J.-X., Migeon, S., Angelier, J., Guennoc, P., Schreiber, D., Michaud, F., Stephan, J.-F. and Sonnette, L. (2011) Structure And Evolution of a Passive Margin in a Compressive Environment: Example of the South-Western Alps-Ligurian Basin Junction during the Cenozoic. Marine Petroleum Geology, 28, 1263-1282. https://doi.org/10.1016/j.marpetgeo.2011.03.012

[155] Larroque, C., Scotti, O. and Ioualalen, M. (2012) Reappraisal of the 1887 Ligurian Earthquake (Western Mediterranean) from Macroseismicity, Active Tectonics and Tsunami Modelling. Geophysical Journal International, 190, 87-104.

[156] Stampfli, G.M. (Ed.) (2001) Geology of the Western Swiss Alps, a Guide-Book. Mémoires de Géologie (Lausanne), 36, 1-194.

[157] Pfiffner, O.A., Schlunegger, F. and Buiter, S.J.H. (2002) The Swiss Alps and Their Peripheral Foreland Basin: Stratigraphic Response to Deep Crustal Processes. Tectonics, 21, 1009. https://doi.org/10.1029/2000TC900039

[158] Dumont, T., Schwartz, S., Guillot, S., Simon-Labric, T., Tricart, P. and Jourdan, S. (2012) Structural and Sedimentary Records of the Oligocene Revolution in the Western Alpine Arc. Journal of Geodynamics, 56-57, 18-38. https://doi.org/10.1016/j.jog.2011.11.006

[159] Malusa, M.G., Polino, R., Zattin, M., Bigazzi, G., Martin, S. and Piana, F. (2005) Miocene to Present Differential Exhumation in the Western Alps: Insights from Fission Track Thermochronology. Tectonics, 24, TC3004. https://doi.org/10.1029/2004TC001782

[160] Handy, M.R., Ustaszewski, K. and Kissling E. (2014) Reconstructing the Alps-CarpathiansDinarides as a Key to Understanding Switches in Subduction Polarity, Slab Gaps and Surface Motion. International Journal of Earth Sciences (Geologische Rundschau), 104, 1-26. https://doi.org/10.1007/s00531-014-1060-3

[161] Tricart, P. (2004) From Extension to Transpression during the Final Exhumation of the Pelvoux and Argentera Massifs, Western Alps. Eclogae Geologica Helveticae, 97, 429-439. https://doi.org/10.1007/s00015-004-1138-1

[162] Leloup, P.H., Arnaud, N., Sobel, E.R. and Lacassin R. (2005) Alpine Thermal and Structural Evolution of the Highest External Crystalline Massif: The Mont Blanc. Tectonics, 24, TC4002. https://doi.org/10.1029/2004TC001676 
[163] Reinecker, J., Danišík, M., Schmid, C., Glotzbach, C., Rahn, M., Frisch, W. and Spiegel, C. (2008) Tectonic Control on the Late Stage Exhumation of the Aar Massif (Switzerland): Constraints from Apatite Fission Track and (U-Th)/He Data. Tectonics, 27, TC6009. https://doi.org/10.1029/2007TC002247

[164] Vernon, A.J., van der Beek, P.A., Sinclair, H.D. and Rahn, M.K. (2008) Increase in Late Neogene Denudation of the European Alps Confirmed by Analysis of a Fission-Track Thermochronology Database. Earth Planetary Science Letters, 270, 316-329. https://doi.org/10.1016/j.epsl.2008.03.053

[165] Glotzbach, C., Reinecker, J., Danišík, M., Rahn, M., Frisch, W. and Spiegel, C. (2010) Thermal History of the Central Gotthard and Aar Massifs, European Alps: Evidence for Steady State, Long-Term Exhumation. Journal of Geophysical Research, 115, F03017. https://doi.org/10.1029/2009JF001304

[166] Sanchez, G., Rolland, Y., Jolivet, M., Brichau, S., Corsini, M. and Carter, A. (2011) Exhumation Controlled by Transcurrent Tectonics: The Argentera-Mercantour Massif (SW Alps). Terra Nova, 23, 116-126. https://doi.org/10.1111/j.1365-3121.2011.00991.x

[167] Egli, D. and Mancktelow, N. (2013) The Structural History of the Mont Blanc Massif with Regard to Models for Its Recent Exhumation. Swiss Journal of Geosciences, 106, 469-489. https://doi.org/10.1007/s00015-013-0153-5

[168] Mosar, J., Stampfli, G.M. and Girod, F. (1996) Western Prealpes Medianes: Timing and Structure-A Review. Eclogae Geologica Helveticae, 89, 389-425.

[169] Burkhard, M. and Sommaruga, A. (1998) Evolution of the Swiss Molasse Basin: Structural Relations with the Alps and the Jura Belt. Geological Society of London Special Publications, 134, 279-298. https://doi.org/10.1144/GSL.SP.1998.134.01.13

[170] Bonnet, C., Malavieille, J. and Mosar J. (2007) Interactions between Tectonics, Erosion, and Sedimentation during the Recent Evolution of the Alpine Orogen: Analogue Modeling Insights. Tectonics, 26, TC6016. https://doi.org/10.1029/2006TC002048

[171] Steck, A. (2008) Tectonics of the Simplon Massif and Lepontine Gneiss Dome: Deformation Structures Due to Collision between the Underthrusting European Plate and the Adriatic Indenter. Swiss Journal of Geosciences, 101, 515-546. https://doi.org/10.1007/s00015-008-1283-Z

[172] Bousquet, R., Schmid, S.M., Zeilinger, G., Oberhansli, R., Rosenberg, C., Molli, G., Christian, R., Wiederkher, M. and Rossi, P. (2012) Tectonic Framework of the Alps. CCGM/CGMW. http://www.geodynalps.org

[173] Persaud, M. and Pfiffner, O.A. (2004) Active Deformation in the Eastern Swiss Alps: PostGlacial Faults, Seismicity and Surface Uplift. Tectonophysics, 385, 59-84. https://doi.org/10.1016/j.tecto.2004.04.020

[174] Ustaszewski, M. and Pfiffner, A. (2008) Neotectonic Faulting, Uplift and Seismicity in the Central and Western Swiss Alps. In: Siegesmund, S., Fugenschuh, B. and Froitzheim, N., Eds., Tectonic Aspects of the Alpine-Dinaride-Carpathian System. Geological Society of London Special Publication, 298, 231-249. https://doi.org/10.1144/SP298.12

[175] Gisler, M., Fah, D. and Deichmann, N. (2004) The Valais Earthquake of December 9, 1755. Eclogae Geologica Helveticae, 97, 411-422. https://doi.org/10.1007/s00015-004-1130-9

[176] Fritsche, S., Fah, D., Gisler, M. and Giardini, D. (2006) Reconstructing the Damage Field of the 1855 Earthquake in Switzerland: Historical Investigations on a Well-Documented Event. Geophysical Journal International, 166, 719-731. https://doi.org/10.1111/j.1365-246X.2006.02994.x

[177] Fritsche, S. and Fah, D. (2009) The 1946 Magnitude 6.1 Earthquake in the Valais: Site- 
Effects as Contributor to the Damage. Swiss Journal of Geosciences, 102, 423. https://doi.org/10.1007/s00015-009-1340-2

[178] Fritsche, S., Fah, D. and Schwarz-Zanetti, G. (2012) Historical Intensity VIII Earthquakes along the Rhone Valley (Valais, Switzerland): Primary and Secondary Effects. Swiss Journal of Geosciences, 105, 1-18. https://doi.org/10.1007/s00015-012-0095-3

[179] Herring, T.A., King, R.W. and McClusky, S.C. (2010) GAMIT Reference Manual, GPS Analysis At MIT, Release 10.4. Department of Earth, Atmospheric and Planetary Sciences, Massachusset Institute of Technology, Cambridge.

[180] Dong, D., Herring, T.A. and King, R.W. (1998) Estimating Regional Deformation from a Combination of Space and Terrestrial Geodetic Data. Journal of Geodesy, 72, 200-214. https://doi.org/10.1007/s001900050161

[181] Cenni, N., Mantovani, E., Baldi, P. and Viti, M. (2012) Present Kinematics of Central and Northern Italy from Continuous GPS Measurements. Journal of Geodynamics, 58, 62-72. https://doi.org/10.1016/j.jog.2012.02.004

[182] Herring, T.A., King, R.W. and McClusky, S.C. (2010) Global Kalman Filter VLBI And GPS Analysis Program, GLOBK Reference Manual, Release 10.4. Department of Earth, Atmospheric and Planetary Sciences, Massachusetts Institute of Technology, Cambridge.

[183] Altamimi, Z., Métivier, L. and Collilieux, X. (2012) ITRF2008 Plate Motion Model. Journal of Geophysical Research, 117, B07402. https://doi.org/10.1029/2011JB008930

[184] Blewitt, G. and Lavallée, D. (2002) Effect of Annual Signals on Geodetic Velocity. Journal of Geophysical Research, 107, 2145. https://doi.org/10.1029/2001JB000570

[185] Bos, M.S., Fernandes, R.M.S., Williams, S.D.P. and Bastos L. (2008) Fast Error Analysis of Continuous GPS Observations. Journal of Geodesy, 82, 157-166. https://doi.org/10.1007/s00190-007-0165-X

[186] Williams, S.D.P., Bock, Y., Fang, P., Jamason, P., Nikolaidis, R-M., Prawirodirdjo, L., Miller, M. and Johnson, J. (2004) Error Analysis of Continuous GPS Position Time Series. Journal of Geophysical Research, 109, B03412. https://doi.org/10.1029/2003JB002741

[187] Williams, S.D.P. (2008) CATS: GPS Coordinate Time Series Analysis Software. GPS Solutions, 12, 147-153. https://doi.org/10.1007/s10291-007-0086-4

[188] Bos, M.S., Bastos, L. and Fernandes, R.M.S. (2010) The Influence of Seasonal Signals on The Estimation of the Tectonic Motion in Short Continuous GPS Time-Series. Journal of Geodynamics, 49, 205-209. https://doi.org/10.1016/j.jog.2009.10.005

[189] Bos, M.S., Fernandes, R.M.S., Williams, S.D.P. and Bastos, L. (2013) Fast Error Analysis of Continuous GNSS Observations with Missing Data. Journal of Geodesy, 87, 351-360. https://doi.org/10.1007/s00190-012-0605-0

[190] Hackl, M., Malservisi, R., Hugentobler, U. and Wonnacott, R. (2011) Estimation of Velocity Uncertainties from GPS Time Series: Examples from the Analysis of the South African Trignet Network. Journal of Geophysical Research, 116, B11404. https://doi.org/10.1029/2010JB008142

[191] Santamaría-Gómez, A., Bouin, M.N., Collilieux, X. and Wöppelmann, G. (2011) Correlated Errors in GPS Position Time Series: Implications for Velocity Estimates. Journal of Geophysical Research, 116, B01405. https://doi.org/10.1029/2010JB007701

[192] Spakman, W. and Wortel, R. (2004) A Tomographic View on Western Mediterranean Geodynamics. In: Cavazza, W., Roure, F., Spakman, W., Stampfli, G.M. and Ziegler, P. Eds., The TRANSMED Atlas, The Mediterranean Region from Crust to Mantle. Springer-Verlag, Berlin-Heidelberg, Berlin, 31-52. https://doi.org/10.1007/978-3-642-18919-7 2 
[193] Lucente, F.P., Margheriti, L., Piromallo, C. and Barruol, G. (2006) Seismic Anisotropy Reveals the Long Route of the Slab through the Western-Central Mediterranean Mantle. Earth Planetary Science Letters, 241, 517-529. https://doi.org/10.1016/j.epsl.2005.10.041

[194] Nocquet, J.-M. (2012) Present-Day Kinematics of the Mediterranean: A Comprehensive Overview of GPS Results. Tectonophysics, 579, 220-242.

https://doi.org/10.1016/j.tecto.2012.03.037

[195] Schellart, W.P. and Moresi, L. (2013) A New Driving Mechanism for Backarc Extension And Backarc Shortening through Slab Sinking Induced Toroidal and Poloidal Mantle Flow: Results from Dynamic Subduction Models with an Overriding Plate. Journal of Geophysical Research Solid Earth, 118, 3221-3248. https://doi.org/10.1002/jgrb.50173

[196] Finetti, I.R. (2005) Crustal Tectono-Stratigraphic Sections across the Western and Eastern Alps from ECORS-CROP and Transalp Seismic Data. In: Finetti, I.R., Ed., Deep Seismic Exploration of the Central Mediterranean and Italy, CROP PROJECT. Elsevier, Amsterdam, Chapter 7, 109-118.

[197] Pfiffner, O.A. (2014) Geology of the Alps. Wiley-Blackwell, Chichester.

[198] Ogniben, L. (1969) Schema Introduttivo Alla Geologia Del Confine Calabro-Lucano. Memorie della Società Geologica Italiana, 8, 453-763.

[199] Salvioni, G. (1957) I Movimenti Del Suolo Nell'italia Centro-Settentrionale, Dati Preliminari Dedotti Dalla Comparazione Di Livellazioni. Bollettino di Geodesia e Scienze Affini, 16, 325-366.

[200] Bondesan, M., Gatti, M. and Russo, P. (1997) Movimenti Verticali Del Suolo Nella Pianura Padana Orientale Desumibili Dai Dati I.G.M. Fino A Tutto Il 1990. Bollettino di Geodesia e Scienze Affini, 56, 141-172.

[201] Tosi, L., Teatini, P., Carbognin, L. and Frankenfield, J. (2007) A New Project to Monitor Land Subsidence in the Northern Venice Coastland (Italy). Environmental Geology, 52, 889-898. https://doi.org/10.1007/s00254-006-0530-8

[202] ARPA (Agenzia Regionale per la Protezione dell'Ambiente) dell'Emilia Romagna (2010) Rete regionale di monitoraggio della subsidenza. http://www.arpa.emr.it/pubblicazioni/reti/generale 227.asp\#

[203] Arca, S. and Berretta, G.P. (1985) Prima Sintesi Geodetica-Geologica Sui Movimenti Verticali Del Suolo Nell'italia Settentrionale. Bollettino di Geodesia e Scienze Affini, 44, 125-156.

[204] DeMets, C., Gordon, R.G., Argus, D.F. and Stein, S. (1994) Effect of Recent Revisions to the Geomagnetic Reversal Time Scale on Estimates of Current Plate Motions. Geophysisical Research Letters, 21, 2191-2194. https://doi.org/10.1029/94GL02118

[205] Argus, D.F., Gordon, R.G., Heflin, M.B., Ma, C., Eanes, R.J., Willis, P., Peltier, W.R. and Owen, S.E. (2010) The Angular Velocities of the Plates and the Velocity of Earth's Centre from Space Geodesy. Geophysical Journal International, 180, 913-960.

[206] DeMets, C., Gordon, R.G. and Argus, D.F. (2010) Geologically Current Plate Motions. Geophysical Journal International, 181, 1-80. https://doi.org/10.1111/j.1365-246X.2009.04491.x 
Submit or recommend next manuscript to SCIRP and we will provide best service for you:

Accepting pre-submission inquiries through Email, Facebook, LinkedIn, Twitter, etc. A wide selection of journals (inclusive of 9 subjects, more than 200 journals)

Providing 24-hour high-quality service

User-friendly online submission system

Fair and swift peer-review system

Efficient typesetting and proofreading procedure

Display of the result of downloads and visits, as well as the number of cited articles

Maximum dissemination of your research work

Submit your manuscript at: http://papersubmission.scirp.org/

Or contact ijg@scirp.org 